\title{
Application of solar energy to seawater desalination in a pilot system based on vacuum multi-effect membrane distillation
}

\author{
J.A. Andrés-Mañas ${ }^{\mathrm{a}, \mathrm{b}}$, L. Roca ${ }^{\mathrm{b}, *}$, A. Ruiz-Aguirre ${ }^{\mathrm{a}, \mathrm{c}}$, F.G. Acién ${ }^{\mathrm{a}}$, J.D. Gil ${ }^{\mathrm{a}}$, G. Zaragoza $^{\mathrm{b}}$ \\ ${ }^{a}$ Universidad de Almería - CIESOL, Ctra. Sacramento s/n, 04120 La Cañada de San Urbano, Almería, Spain \\ ${ }^{\mathrm{b}}$ CIEMAT - Plataforma Solar de Almería, Ctra. De Senés s/n, 04200 Tabernas, Almería, Spain \\ ${ }^{\mathrm{c}}$ Dipartimento dell'Innovazione Industriale e Digitale (DIID) - Ingegneria Chimica, Gestionale, Informatica, Meccanica, Università degli Studi di Palermo (UNIPA), \\ Palermo, Italy
}

\section{H I G H L I G H T S}

- Assessment of a pilot-scale solar vacuum multi-effect membrane distillation system.

- Use of heat storage allowed operating with discontinuous solar radiation.

- Different operational strategies depending on heat temperature setpoint assessed.

- Total annual production of $70.5 \mathrm{~m}^{3}$ distilled water with $35.9 \mathrm{~m}^{2}$ solar field.

\section{A R T I C L E I N F O}

\section{Keywords:}

Solar desalination

Membrane distillation

Vacuum-multi-effect

Thermal storage

Experimental pilot-scale

\begin{abstract}
A B S T R A C T
The evaluation of a novel solar seawater desalination system implemented at the University of Almeria (Spain) is presented. It integrates a solar thermal field based on static collectors and a thermal desalination system based on the vacuum multi-effect membrane distillation technology. The distillation unit has a particular innovation to increase its thermal performance, using a seawater flow to condense the steam and preheat the feed. Experiments were made under different environmental conditions to assess the role of the thermal storage system for minimizing the effect of disturbances in solar radiation. Thermal energy could be delivered at a stable temperature to the distillation module, even with variable solar radiation. A simulation analysis based on a quasi-dynamic model was also performed to evaluate the distillate production profile and the operating time during a typical year considering different temperature setpoints at the inlet of the membrane module (60, 70, and $80^{\circ} \mathrm{C}$ ). The simulated volume of distilled water generated annually ranged from 41.7 to $70.5 \mathrm{~m}^{3}$, depending on the setpoint. The membrane distillation unit produced water almost uniformly along the year, with an average flux of $(5.5 \pm 1) 1 \mathrm{~h}^{-1} \mathrm{~m}^{-2}$ at the maximum setpoint, which was proved the most favourable.
\end{abstract}

\section{Introduction}

The increasing water scarcity in many regions and the worldwide energy crisis are two of the harshest problems in the 21st century, especially in overpopulated areas with low technological development [1]. Only $3-5 \%$ of water on Earth is fresh water suitable for agricultural and industrial activities. It is essential for the economic development, so countries worldwide are forced to find new technologies for its production [2]. In this sense, it is vital to find novel robust processes for obtaining fresh water from brackish or saltwater sources with the least energy consumption and as autonomously as possible, with no requirements of specialized workforce [3].
Desalination is a widespread process for obtaining fresh water, either from seawater or from brackish water sources. It is fully implemented at large scale nowadays and allows supplying fresh water to large populations. However, rural areas may not receive desalinated water if there are no suitable pipelines and energy supply, thus a decentralized supply using small-scale plants is more adequate in many cases. Standalone production of fresh water in a small scale requires a source of energy, and the use of renewable energies is a great opportunity for increased sustainability of the concept $[4,5]$. Since the regions that present higher levels of water scarcity are those with the highest availability of solar radiation (placed in the solar belt), the utilization of solar energy takes on special interest.

\footnotetext{
* Corresponding author.

E-mail address: lidia.roca@psa.es (L. Roca).
} 


\begin{tabular}{|c|c|}
\hline \multicolumn{2}{|c|}{ Nomenclature } \\
\hline variable & description [units] \\
\hline $\mathrm{A}_{\mathrm{s}}$ & cross-section area of the loop pipe $\left[\mathrm{m}^{2}\right]$ \\
\hline$c_{p}$ & specific heat capacity $\left[\mathrm{J} \cdot \mathrm{kg}^{-1} \cdot{ }^{\circ} \mathrm{C}^{-1}\right]$ \\
\hline d & distillate production rate $\left[1 \cdot \mathrm{h}^{-1}\right]$ \\
\hline $\mathrm{H}$ & thermal losses coefficient $\left[\mathrm{J} \cdot \mathrm{s}^{-1} \cdot{ }^{\circ} \mathrm{C}^{-1}\right]$ \\
\hline I & solar irradiance $\left[\mathrm{W} \cdot \mathrm{m}^{-2}\right]$ \\
\hline $\mathrm{L}$ & flat plate tube length [m] \\
\hline $\mathrm{L}_{\mathrm{eq}}$ & equivalent flat plate tube length [m] \\
\hline$\dot{m}_{m d}$ & $\begin{array}{l}\text { water mass flow rate between the heat exchanger and the } \\
\text { MD module }\end{array}$ \\
\hline$\dot{m}_{h x}$ & $\begin{array}{l}\text { water mass flow rate between the } 3 \text {-way valve and the } \\
\text { heat exchanger }\left[\mathrm{kg} \cdot \mathrm{s}^{-1}\right]\end{array}$ \\
\hline$\dot{m}_{e q}$ & equivalent mass flow rate $\left[\mathrm{kg} \cdot \mathrm{s}^{-1}\right]$ \\
\hline$\dot{m}_{s}$ & solar field mass flow rate $\left[\mathrm{kg} \cdot \mathrm{s}^{-1}\right]$ \\
\hline$\dot{m}_{t}$ & $\begin{array}{l}\text { solar fluid mass flow rate between the tank and the three- } \\
\text { way valve }\left[\mathrm{kg} \cdot \mathrm{s}^{-1}\right]\end{array}$ \\
\hline $\mathrm{n}_{\mathrm{a}}$ & number of tubes in each flat plate collector $[-]$ \\
\hline $\mathrm{n}_{\mathrm{p}}$ & number of flat plate collectors in parallel connection [-] \\
\hline $\mathrm{n}_{\mathrm{s}}$ & number of flat-plate collectors in series connection $[-]$ \\
\hline SP & $\begin{array}{l}\text { temperature setpoint at the inlet of the membrane module } \\
{\left[{ }^{\circ} \mathrm{C}\right]}\end{array}$ \\
\hline $\mathrm{T}_{\mathrm{a}}$ & ambient temperature $\left[{ }^{\circ} \mathrm{C}\right]$ \\
\hline $\mathrm{T}_{\mathrm{md}, \text { in }}$ & $\begin{array}{l}\text { hot water temperature at the inlet of the membrane } \\
\text { module }\left[{ }^{\circ} \mathrm{C}\right]\end{array}$ \\
\hline $\mathrm{T}_{\text {md,out }}$ & $\begin{array}{l}\text { water temperature from the MD module to the heat ex- } \\
\text { changer }\left[{ }^{\circ} \mathrm{C}\right]\end{array}$ \\
\hline $\mathrm{T}_{\mathrm{hx}, \mathrm{in}}$ & $\begin{array}{l}\text { hot fluid temperature at the inlet of the heat exchanger } \\
\text { (inlet of the MD unit) }\left[{ }^{\circ} \mathrm{C}\right]\end{array}$ \\
\hline $\mathrm{T}_{\text {hx,out }}$ & fluid temperature from the heat exchanger to the tank $\left[{ }^{\circ} \mathrm{C}\right]$ \\
\hline
\end{tabular}

$\bar{T}_{s} \quad$ mean temperature in the solar field $\left[{ }^{\circ} \mathrm{C}\right]$

$\mathrm{T}_{\mathrm{s}, \text { in }} \quad$ inlet temperature of the solar field $\left[{ }^{\circ} \mathrm{C}\right]$

$\mathrm{T}_{\mathrm{s}, \text { out }} \quad$ outlet temperature of the solar field $\left[{ }^{\circ} \mathrm{C}\right]$

$\mathrm{T}_{\mathrm{sw}} \quad$ seawater temperature $\left[{ }^{\circ} \mathrm{C}\right]$

$\mathrm{T}_{\mathrm{t} 1} \quad$ solar fluid temperature in the upper part of the tank $\left[{ }^{\circ} \mathrm{C}\right]$

$\mathrm{T}_{\mathrm{t} 2} \quad$ solar fluid temperature in the lower part of the tank $\left[{ }^{\circ} \mathrm{C}\right]$

$\mathrm{UA}_{1}$ tank thermal losses coefficient (upper part) $\left[\mathrm{J} \cdot \mathrm{s}^{-1} \cdot{ }^{\circ} \mathrm{C}^{-1}\right]$

$\mathrm{UA}_{2}$ tank thermal losses coefficient (lower part) $\left[\mathrm{J} \cdot \mathrm{s}^{-1} \cdot{ }^{\circ} \mathrm{C}^{-1}\right]$

$\mathrm{V} \quad$ volume of the tank $\left[\mathrm{m}^{3}\right]$

\section{Greek letters}

$\beta \quad$ tuning parameter that modulates the solar irradiance collection [m]

$\rho \quad$ solar fluid density $\left[\mathrm{kg} \cdot \mathrm{m}^{-3}\right]$

$\gamma \quad$ three-way valve aperture parameter [-]

List of abbreviations

AGMD air gap membrane distillation

GOR gained output ratio

MD membrane distillation

MED multi-effect distillation

MSF multi-stage flash

PGMD permeate gap membrane distillation

PVGIS photovoltaic geographical information system

RO reverse osmosis

SCADA supervisory control and data acquisition

SMD solar membrane distillation

VMD vacuum membrane distillation

V-MEMD vacuum multi-effect membrane distillation
Desalination driven by solar energy is thus a promising solution to the water scarcity problems in isolated rural areas with low demand (less than $20 \mathrm{~m}^{3}$ day $^{-1}$ ) and the lack of an appropriate continuous supply of energy [6]. The use of photovoltaic fields for supplying electricity to reverse osmosis (RO) units is an ongoing option [7]. However, problems with the performance have been observed. RO is a very energy-demanding process that should operate continuously, and solar energy is discontinuous by nature. This fact derived in operational difficulties even at pilot scale [8]. The use of solar energy as thermal source for desalination is more straightforward because storing heat is much simpler than storing electricity [9]. Thermal energy can be transmitted to saltwater directly, making it flow through a field of solar collectors, or indirectly, by connecting the desalination unit through a heat exchanger to a solar field operating in closed loop using a specific solar fluid in the collectors. By far, the most commonly used strategy is the latter, due to the accelerated damage that hot saline water would produce in the internal piping of the panels, ending in higher operational costs [10]. To achieve an economically affordable process, the solar collectors must have high efficiency, and the desalination units must make the most of the energy. Solar stills are systems with very low operational and maintenance costs, but with large investment costs because of their low energy efficiency and low production (around $1.2 \mathrm{~m}^{3} \mathrm{~m}^{-2} \mathrm{y}^{-1}$ ). Multi-stage flash (MSF) and multi-effect distillation (MED) have much higher efficiencies, but they are technologies only competitive on a large scale and with high maintenance costs, mainly due to scaling and corrosion [11].

An inexpensive future alternative with great potential in the desalination of seawater or highly saline sources coupled to solar systems is membrane distillation (MD). It is a non-isothermal membrane process with simultaneous mass and heat transfer, fully implementable on both small and medium scale, with good energy efficiency and low cost. Water molecules from a hot current pass in vapor phase through a hydrophobic microporous membrane, driven by the vapor pressure difference between both sides of it. Working temperatures are low, below $80-85^{\circ} \mathrm{C}$, in order not to exceed the thermal resistance of the membrane. Working pressures do not need to be higher than the atmospheric because, unlike in other membrane processes like RO, the driving force is not mechanical pressure but vapor pressure. Thus, as in thermal desalination processes, the rejection of solutes is almost $100 \%$, and chemical pretreatments are theoretically not necessary. The MD process yields fresh water with suitable parameters of quality and healthiness. Materials used for modules are usually plastics, cheaper, free of corrosion and fouling. On the other hand, MD can be subjected to membrane wetting (which causes contamination of the product), temperature polarization, and heat losses by conduction across the membrane, which reduce the energy efficiency [12]. Nowadays, there are no specific membranes for MD available commercially, but the development of membranes is increasing, to improve their mass and heat transfer properties and avoid the pitfalls commented above [13].

Several MD systems have been studied for proofing the concept $[14,15]$. The main challenge of MD at pilot scale is its high energy consumption. New configurations and working strategies are being researched, taking as challenging goal the production of distilled water with an affordable specific energy consumption [16]. Nowadays, different layouts of membrane, and several configurations based on different ways of condensing the vapor are being introduced in pilot units and commercial prototypes for their evaluation [17]. Moreover, the coupling of MD systems with solar energy is growing in popularity and is being studied at the same time as new configurations [7,18]. The assessment of air gap (AGMD) and permeate gap (PGMD) plate and frame membrane modules for solar desalination was performed at Plataforma Solar de Almeria [19,20]. The main problem with these modules was their poor internal heat recovery, which led to high thermal energy consumption and therefore the necessity of large solar 
fields that increase the investment costs [21].

An improvement on that design is the spiral-wound concept [22]. Several solar desalination systems based on spiral-wound modules have been installed for assessing their distillate productions and their abilities in the supply of fresh water in isolated zones [10,23]. As part of the SMADES project, an autonomous desalination system was developed and installed in a rural coastal area of Jordan. It was formed by four spiral-wound modules, which worked in parallel in permeate gap (PGMD) mode, a photovoltaic field and a solar thermal field. Low water recovery of $5 \%$ was achieved in this system, but with a standalone installation, able to work with an unstable energy source and with no need of chemical pretreatments $[24,25]$. One of the weaknesses of the spiral-wound modules, however, is managing the non-condensable gases, which requires deaeration with the subsequent energy loss [26]. Another weak point is the fact that latent heat of condensation is recovered as sensible heat to preheat the feed, which reflects strongly in the trade-off between productivity and energy efficiency that is characteristic of the MD process [27]. Using simulated seawater as feed flow, several modules working in AGMD and PGMD modes with sensible heat recovery were studied using solar thermal energy as heat source [28]. Values of gained output ratio (GOR) up to 7 in spiralwound AGMD modules with several envelopes and up to 3.5 in PGMD modules with single envelope were obtained, with distillate fluxes of $1.01 \mathrm{~h}^{-1} \mathrm{~m}^{-2}$ and $1.81 \mathrm{~h}^{-1} \mathrm{~m}^{-2}$, respectively [29].

Vacuum membrane distillation (VMD) has also been evaluated using solar thermal energy [30]. In this MD operational mode, by using a vacuum pump, the absolute pressure inside the membrane module is reduced, the feed is boiled with lower thermal energy demand and the volume of vapor produced is increased, and thus the distillate production. Several studies were focused on the modelling and design with different membrane geometries, like flat sheet [31,32] and hollow fiber [33]. However, upscaling of VMD was not done until memsys launched their novel plate-and-frame modules for vacuum multi-effect MD (VMEMD) in 2010. Their particular configuration allows removing noncondensable gases efficiently, improving thus the energy efficiency $[34,35]$. Early modules showed similar energy efficiencies than spiralwound modules with much larger concentration factors [36]. As in the case of MED, latent heat recovery in multi-effect units means an increase in both productivity and energy efficiency, and therefore the chance of concentrating water sources even more. A study was reported in which a solution with up to $22.0 \mathrm{wt} \%$ of salts (very close to saturation) was desalinated during six months. A distillate productivity of $7.01 \mathrm{~h}^{-1} \mathrm{~m}^{-2}$ was obtained using a two-effect V-MEMD module [37]. More recently, a performance evaluation of a four-effect V-MEMD module with prepared feed brackish water [38] was also presented.

There are numerous studies of solar membrane distillation. An extensive review of the current technology and future perspectives for increasing the energy efficiency was presented in [39]. Different geometries and operational modes have been proposed to deal with this challenge, beyond the classical coupling between solar panels and an MD module. Li et al. [40] developed a hollow-fibre MD prototype with membrane fibres integrated inside evacuated tube collectors. This way, thermal energy was directly harvested simultaneously to the permeate production, what minimized the heat losses. In addition to these new concepts, optimization studies of the whole solar MD plants depending on the operational and ambient conditions are also carried out [41]. However, there are not many studies of V-MEMD operated with solar energy. A proposal for using a hybrid solar-waste heat V-MEMD desalination system for supplying drinking water $24 \mathrm{~h}$ a day in a remote area of northern Chile was reported [42]. Furthermore, a standalone solar thermal and photovoltaic system was developed and tested with lowsalt water as feed $\left(2.3 \mathrm{mS} \mathrm{cm} \mathrm{cm}^{-1}\right)$. It included a heat pump, a heat storage tank, and a four-effect memsys V-MEMD module [43]. One of the drawbacks of that system was that a significant amount of electricity was required in the heat pump to condensate the steam in the condenser. An improved energy-saving version of a memsys V-MEMD module was presented in [44], in which the feed seawater itself was used inside the condenser for cooling down the vapor from the last effect. High distillate fluxes (up to $8.51 \mathrm{~h}^{-1} \mathrm{~m}^{-2}$ ) and GOR values (up to 3.19) were obtained, but the performance was strongly dependent on the season, given that the seawater temperature determined the vapor condensation.

In this study, the same module as in [44] was considered and the use of solar heat as the only thermal energy supply for the MD process (without the need of a heat pump) was investigated. In addition, the results obtained from this experimental analysis were an essential input to model the V-MEMD system and evaluate the distillate production profile over a whole year using solar energy as the only thermal energy

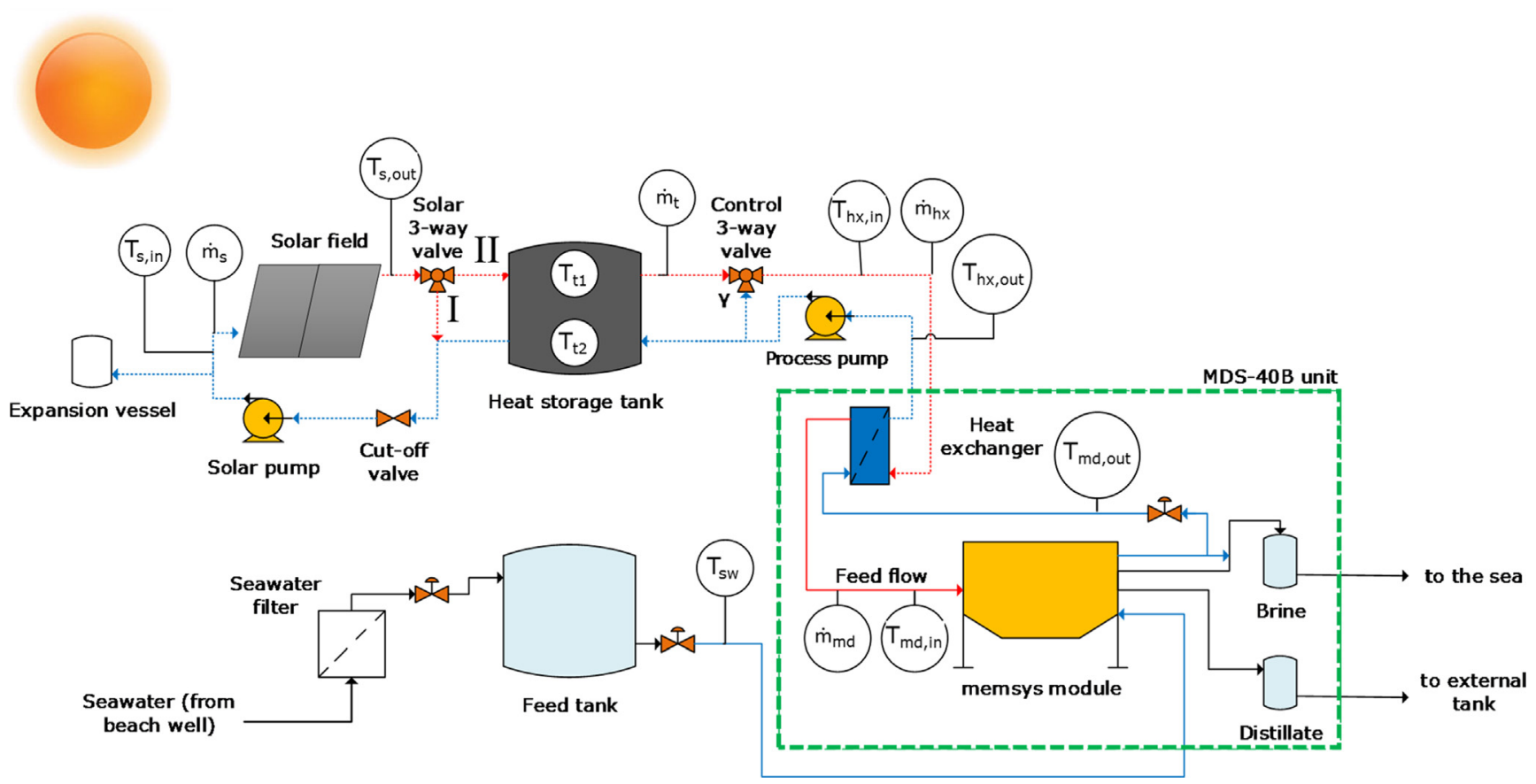

Fig. 1. Layout of the solar desalination system and main variables used in the model. 
source. This kind of models that include the solar heat process and the membrane distillation system can be used for different applications, such as analyzing the production and consumption over a period of time, evaluating control strategies to improve the operation or optimizing the system design attending to different criteria. In [32] for example, a VMD system directly integrated with solar collectors (to heat the feed water directly in the evaporation channel, with vacuum in the permeate side) was modelled and simulated to compare the production in four different days and evaluate it over a whole year. In [45], dynamic and static models were combined to compare the results obtained with different function objectives in a model predictive controller aimed to optimize the operation of solar MD facility. Regarding design optimization, it is worth mentioning the recent work by Moore et al. [46], in which PV and thermal collectors were combined to electrically and thermally feed a hollow fiber MD module. In that case, a complete model of the proposed facility was used in an optimization problem to minimize the cost of the water while satisfying a production goal.

This work analyzes the operation and performance of the solar desalination plant installed at the University of Almeria using real seawater, with the goal of demonstrating how the variability of solar radiation is dealt with to optimize the performance of the MD system. The main hypothesis is that stable operation can be achieved in the VMEMD module. Tests were carried out during different periods of the year, to evaluate the behavior of the system along different weather conditions, comparing days with high solar radiation, days with disturbances in the solar radiation, and days with practically no solar radiation at all. A further objective of this study was to perform an annual evaluation of the solar V-MEMD facility, assessing the effect of the operation parameters on the production profile over a year and different strategies for using the heat. This was done using the model referred above and comparing three temperature setpoints.

\section{Materials and methods}

\subsection{Experimental setup}

The solar desalination MD system operated in this work was installed at the University of Almería, close to the seashore and using a beach well for the intake of feed seawater, and with good incidence of solar radiation from sunrise to sunset. The system layout and the main variables used in the subsequent simulation are shown in Fig. 1.

\subsubsection{Solar system with thermal storage}

To supply the necessary thermal energy for carrying out the desalination process, a solar field with five racks of three flat plate collectors each (Euro L20 AR, by Wagner \& Co., Germany) and total aperture area $35.9 \mathrm{~m}^{2}$ was used. The solar fluid was water with $30 \mathrm{vol} \%$ antifreeze (DC20, Wagner \& Co., Germany). The panels were tilted $45^{\circ}$ and worked at 2-2.5 atm internal pressure. To ensure uniformity in the solar fluid flow rate and in the temperature distribution inside the whole circuit, racks were hydraulically connected in reverse feeding mode. In these conditions, the nominal thermal power supplied was up to 17 $\mathrm{kW}_{\text {th }}$ at $90^{\circ} \mathrm{C}$, enough for meeting the requirements of the desalination module.

The solar system was fully monitored and connected to a hydraulic frame that bears the flowmeters (Promag 50P40, Endress + Hauser AG, Switzerland) and pumps (Solar 25-120, Grundfos TM, Sweden). Temperatures in the solar system were measured using several Pt-100 probes (Omnigrad TST90, Endress + Hauser AG, Switzerland) installed in each pipeline. Some relief valves and pressure sensors (Cerabar T PMP-131, Endress + Hauser AG, Switzerland) were installed in order to protect the system against overpressure. Copper piping was thermally insulated to avoid excessive thermal losses.

An innovative element introduced in this solar system was an electronic valve installed upstream in the primary solar circuit, which allowed starting the system up even when the stagnant temperature at the solar collectors was above the fluid's boiling point. This was especially useful when the solar field needed to be stopped for excessive temperature. The valve (called cut-off valve in Fig. 1) cut the circuit off when the system was not working, driving the vaporized fluid from the solar panels to the expansion vessel, which was big enough to collect all the volume of the solar fluid. This fluid condensed inside the expansion vessel and flowed back to the solar panels when the pump was turned on.

A 15001 tank (PSX-F, Huch GmbH, Germany), fully enveloped with a thick insulation coat, was connected to the solar field to store heat during periods of excessive energy to be used when solar energy was not immediately available. It also acted as a heat buffer, using an electronic control 3-way valve (Fig. 1), for minimizing short-time disturbances of temperature caused by unstable solar radiation in cloudy days and facilitating the temperature control at the inlet of the desalination unit. Data acquisition and control of every electronic element were made using a Supervisory Control And Data Acquisition (SCADA) software.

The needs of electricity for operating the desalination system were met with the grid at the University of Almería, although they could be satisfied with a photovoltaic system. Since the main energy consumption in the desalination process is related to thermal energy, this paper is not focused on the evaluation of electricity needs.

\subsubsection{V-MEMD Unit}

The commercial pilot V-MEMD desalination unit used in the present study was called MDS-40B and was assembled and manufactured by the Dutch company Aquaver BV. The MD module was developed and patented by memsys $\mathrm{GmbH}$ and consisted of a steam raiser, four evaporation-condensation effects, and a condenser. Its total membrane area was $6.4 \mathrm{~m}^{2}$. The module operated with absolute pressure even lower than 100 mbar. The main innovation introduced in this desalination unit was the use of feed seawater as coolant in the condenser for preheating it, recovering the latent heat of condensation of the vapor coming from the last effect and improving thus the thermal energy efficiency. More details of the unit are given in [44].

\subsection{Experimental procedure}

The experimental campaign consisted on tests for evaluating the performance of the solar desalination system (Fig. 1). Operational conditions in the solar system were such that the inlet temperature $\left(\mathrm{T}_{\mathrm{md}, \text { in }}\right)$ and the seawater feed flow rate (F1) in the desalination module were maintained stable, regardless of the weather conditions. Due to thermal limitations of the membranes, $\mathrm{T}_{\mathrm{md} \text {,in }}$ could not be higher than $80^{\circ} \mathrm{C}$. Therefore, the temperature of the solar fluid from the tank to the heat exchanger of the MDS-40B $\left(\mathrm{T}_{\mathrm{hx}, \text { in }}\right)$ was kept below $90^{\circ} \mathrm{C}$. The flow rate of solar liquid from the tank to the heat exchanger in the MD unit $\left(\dot{\mathrm{m}}_{\mathrm{t}}\right)$ was regulated by a control 3-way valve.

To achieve the desired operating conditions, the strategy changed depending on the ambient conditions. In the case of days with abundance of solar radiation, the solar pump was connected, and the solar field linked to the heat storage tank by means of a regulation solar 3way valve for loading the latter and supplying thermal energy to the desalination unit. Two flow directions, showed in Fig. 1, were separated by this 3-way valve, but only path II was interesting for the simulations performed in this study. Path I was only considered experimentally and represents the closed loop of solar fluid maintained just after starting the system in the early morning, when enough solar radiation is expected but not yet available to increase the temperature. In addition, the solar 3-way valve in path I allowed to start the desalination unit earlier in the morning by using stored heat from the tank, while the solar field fluid was heating up separately. Heat could be also stored at the same time the desalination unit operated, if there was a surplus of thermal energy in relation to the needs of the desalination device. This 
important fact makes the system robust to disturbances in solar radiation and allowed to operate in the other cases, with hindered or negligible external energy. When not enough solar power was available, the solar field was isolated by closing the cut-off valve and the desalination module worked with previously stored thermal energy, in closed loop with the buffer storage tank.

In any case, the operation of the desalination system started when the vacuum pump of the desalination device was connected, and feed seawater was sucked by the vacuum to the condenser. Seawater acted as a coolant and was consequently preheated in operation by the latent heat of condensation transferred by the vapor coming from the last effect of the module. Cooling seawater went out of the condenser and then, regulated by a manual valve, part of it was discarded back to the sea with the brine, and the rest (the feed flow rate, F1) entered the heat exchanger as the saline feed to the MD process. When F1 was stable and close to the desired setpoint, the process pump was switched on, delivering the solar thermal energy from the storage tank to the heat exchanger of the MDS-40B unit. The aperture of the control 3-way valve $(\gamma)$ allowed the mixing of the hot flow with the cold return to control the temperature and reach the desired setpoint of $\mathrm{T}_{\mathrm{hx} \text {,in }}$. The feed, heated from $T_{m d, o u t}$ to $T_{m d, i n}$, entered the steam raiser of the vacuum desalination module and the distillation occurred as explained in detail in the V-MEMD literature (see e.g. $[39,44,47]$ ): the vapor passed through the membrane pores and was condensed in each effect by the liquid saline flow flowing in counter-current from the condenser; the latent heat of condensation released by the vapor phase in each effect was used to concentrate the feed as it advanced through the brine channel of the module. The vapor from the last effect was cooled down with the initial feed current in the condenser. The distillate was stored in an auxiliary tank, and the brine was discarded to the sea.

Solar radiation data, temperatures, pressures and flow rates in the solar circuit were all recorded by the SCADA system. The amounts of energy captured, used for desalination and stored in the buffer tank, respectively, were estimated. On the other hand, the vacuum pressure inside the condenser, the feed flow rate and its temperature were registered by the MDS-40B unit, as well as the distillate production and its quality. To certify the accuracy of these electronic measurements, an external control of the distillate parameters was performed regularly.

\section{Experimental assessment of the operation with solar thermal energy}

Seawater temperature and solar irradiance cannot be controlled, so tests were performed during several hours per day, in days with different enough ambient conditions, and dealing with their natural variations to achieve the desired operating conditions. Thus, as explained in the previous section, the operational procedure changed depending on the ambient conditions. The three typical cases (abundant, disturbed, and negligible solar radiation) were assessed and the corresponding operation and performances are described in this section.

\subsection{Operation in clear days}

The amount of incident solar radiation in Almeria during a big fraction of the daylight hours on clear days (greater than $1000 \mathrm{~W} \mathrm{~m}^{-2}$ ) allowed operating the membrane module at high temperature. Fig. 2 shows the data taken from an experiment performed with feed temperature $\left(T_{m d, i n}\right)$ setpoint (SP) of $80^{\circ} \mathrm{C}$ and feed flow rate setpoint of $1201 \mathrm{~h}^{-1}$ on a day close to the summer solstice. The dashed-dotted red line represents the incident solar radiation to the solar panels. The evolution of the feed temperature that entered into the MD module is represented with a continuous yellow line, and the temperature of the liquid that flowed out of the solar panels is in dashed blue. With high and stable solar radiation, it was possible to work very close to the setpoint value of temperature almost two hours before solar noon. The MDS-40B unit was started at about 08:35, when solar radiation was about $700 \mathrm{~W} \mathrm{~m}^{-2}$ and $\mathrm{T}_{\mathrm{md} \text {,in }}$ was $70^{\circ} \mathrm{C}$. Although the setpoint value of feed temperature $\left(80^{\circ} \mathrm{C}\right)$ was reached at $10: 15$, the distillate production started before, because the amount of thermal energy available at 8:35 was already enough. When the setpoint value was reached and kept constant, the system worked steady and the distillate flux in these operating conditions was $7.21 \mathrm{~h}^{-1} \mathrm{~m}^{-2}$.

The amount of solar energy harvested by the panels in a clear day was higher than that needed for desalination in the MDS-40B unit. With the facility presented in this work, it was possible to store the surplus of heat for its use in case of absence of solar radiation. Fig. 3 shows the accumulated energy distribution corresponding to the experiment of Fig. 2. Since around 8:30, the solar field was able to yield thermal energy at an almost constant power of around $16.5 \mathrm{~kW}_{\mathrm{th}}$. Part of that energy was supplied for heating the feed to produce distillate (continuous purple line), and the rest was stored (dashed grey line). The amount of energy stored during this experiment was around $20 \mathrm{kWh}_{\mathrm{th}}$, $34 \%$ of the total energy collected by the solar field (dashed-dotted green line). As mentioned before, $\mathrm{T}_{\mathrm{md} \text {,in }}$ and $\mathrm{F} 1$ were maintained very close to their setpoint values $\left(80^{\circ} \mathrm{C}\right.$ and $120 \mathrm{~h} \mathrm{~h}^{-1}$, respectively) since about 10:15. Before that, the module produced distillate in unsteady

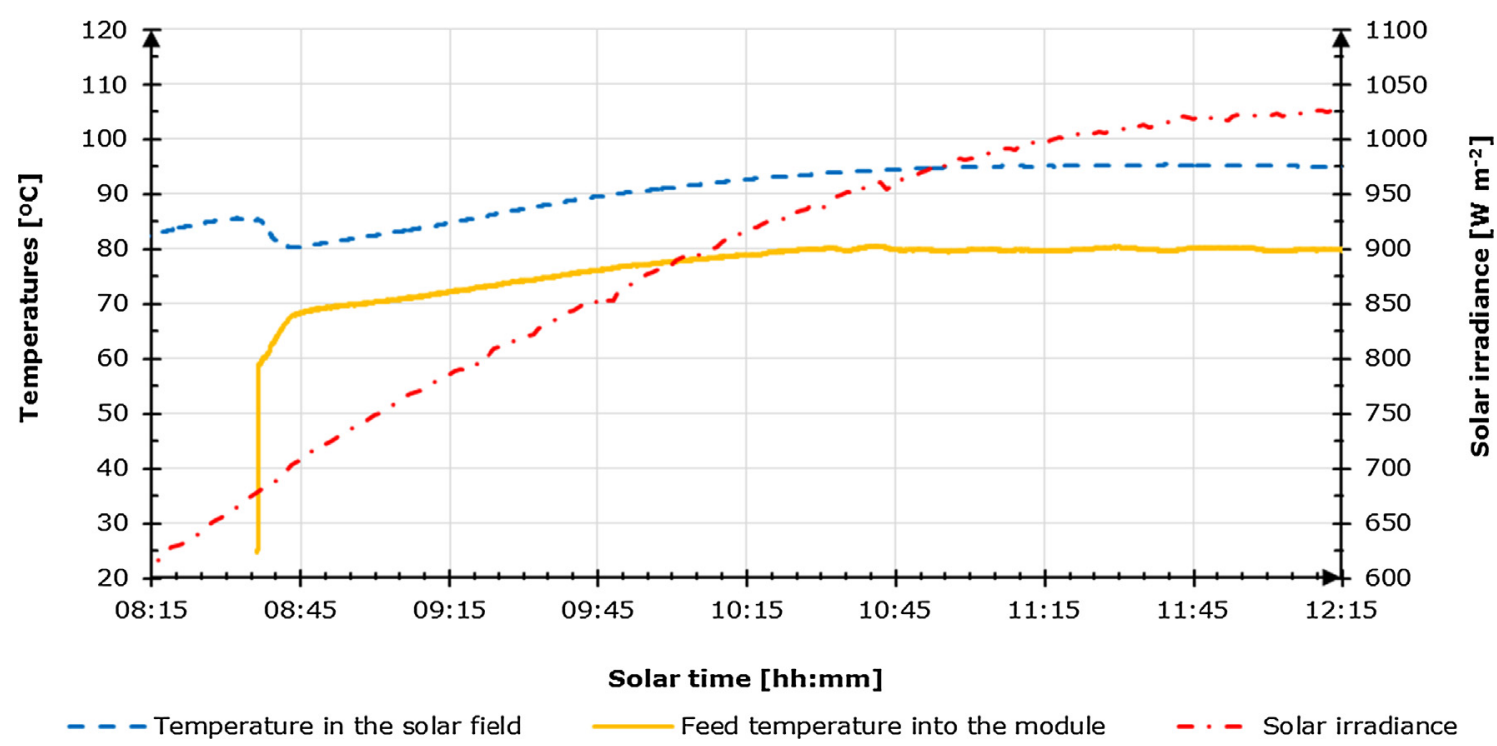

Fig. 2. System temperatures and solar radiation in the experiment performed in a clear day. 


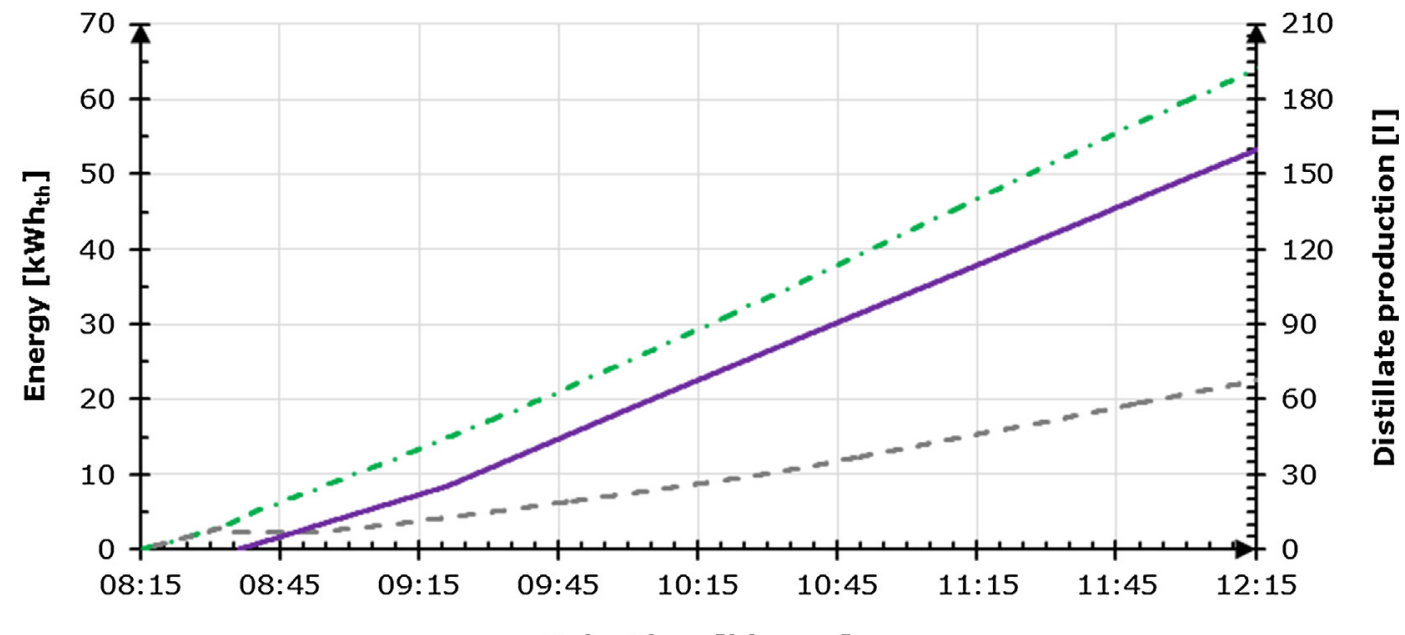

Solar time [hh:mm]

\section{- - Captured solar energy _ - - Stored solar energy — Distillate production}

Fig. 3. Accumulated energy and distillate production in the experiment performed in a clear day.

state. In Fig. 3 it can be seen that the distillate production was maintained almost at a constant rate since about 09:30, when $\mathrm{T}_{\mathrm{md} \text {,in }}$ reached $75^{\circ} \mathrm{C}$.

\subsection{Operation with disturbances in solar radiation}

Fig. 4 shows the data collected on a day when solar radiation was unstable due to clouds. The setpoint of feed temperature was $60{ }^{\circ} \mathrm{C}$, and of feed flow rate $120 \mathrm{lh}^{-1}$. Despite the strong variations of solar radiation observed, the unit could be operated at the desired temperature.

Solar radiation had almost no disturbances in the beginning of operation from 07:55 to 09:40. In this timespan, the temperature of solar fluid increased almost linearly from 65 to $75^{\circ} \mathrm{C}$. After 09:40, disturbances in solar radiation occurred. Consequently, the temperature of the solar fluid was reduced about $10^{\circ} \mathrm{C}$ and could not be controlled well. However, the feed seawater temperature was maintained close to the setpoint during all the time, even with low and variable solar radiation. This operation was possible by using the buffer tank in the solar field, which absorbed the variations of radiation successfully. Fig. 5 illustrates the energy distribution in this test. It can be seen that at the times when the solar radiation decreased, the rate of captured solar energy decreased and so did the stored solar energy, which showed a negative slope indicating that stored heat was used to keep the feed seawater temperature constant. Thus, the distillate flux was also maintained practically constant around $2.71 \mathrm{~h}^{-1} \mathrm{~m}^{-2}$, as indicated by the constant slope of the continuous purple line in Fig. 5 .

\subsection{Operation with only stored heat}

Fig. 6 shows the data taken from operation on a rainy day in Almeria. Dashed-dotted red line represents the poor solar radiation during all that day (never above $300 \mathrm{Wm}^{-2}$ ). Despite the solar field being turned off (dashed blue line indicating ambient temperature), the feed temperature was maintained around the setpoint value of $60^{\circ} \mathrm{C}$ for $4.5 \mathrm{~h}$, using exclusively heat that was stored in the previous days while the operation was carried out with high solar radiation.

As shown in Fig. 7, the stored heat initially available was around 30 $\mathrm{kWh}_{\mathrm{th}}$, and the MDS-40B unit was supplied with $6.2 \mathrm{~kW}_{\text {th }}$ steadily, producing distillate with a constant flux of $2.41 \mathrm{~h}^{-1} \mathrm{~m}^{-2}$ during almost $4.5 \mathrm{~h}$ of operation. As in the previous case, the continuous purple line in

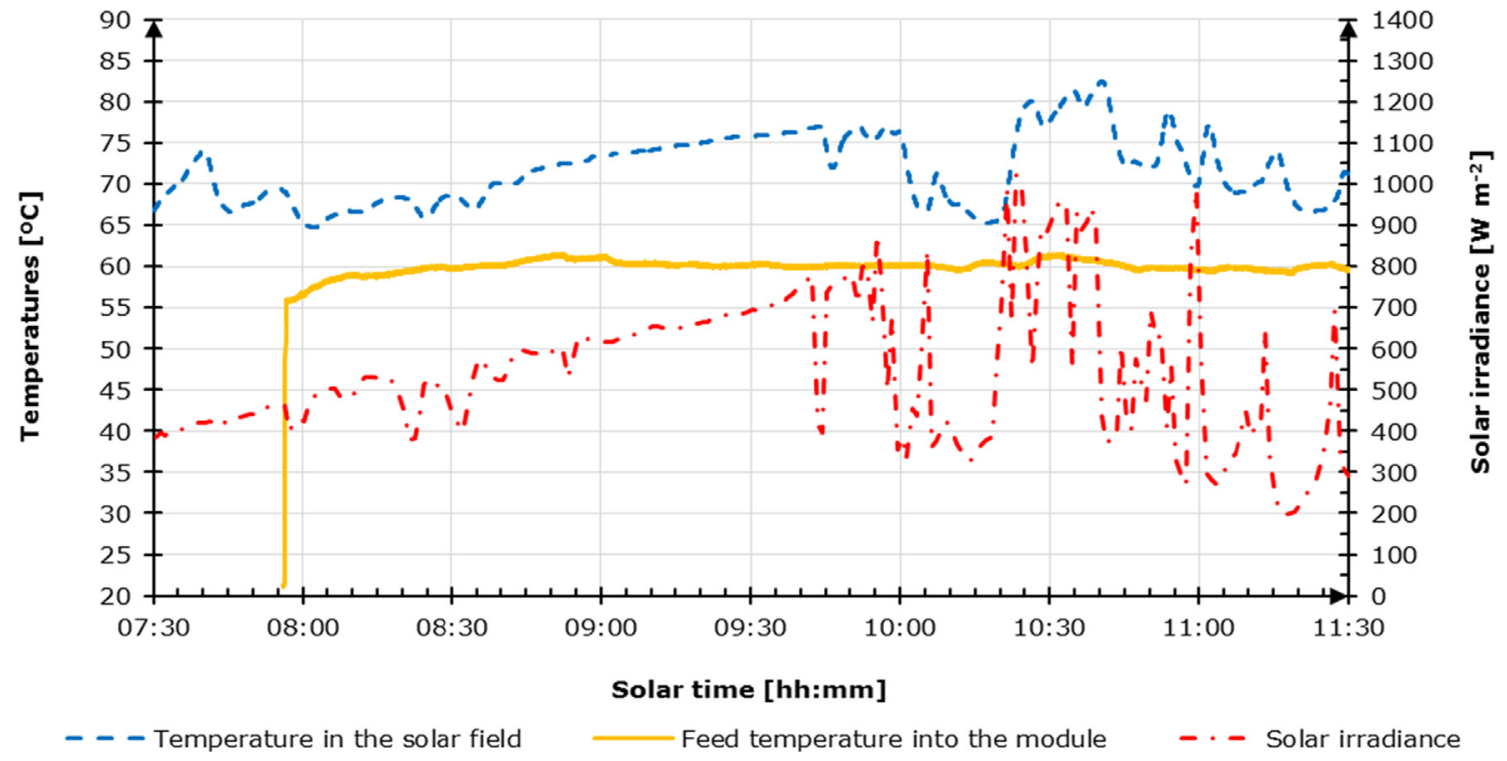

Fig. 4. System temperatures and solar radiation in the experiment performed in a cloudy day. 


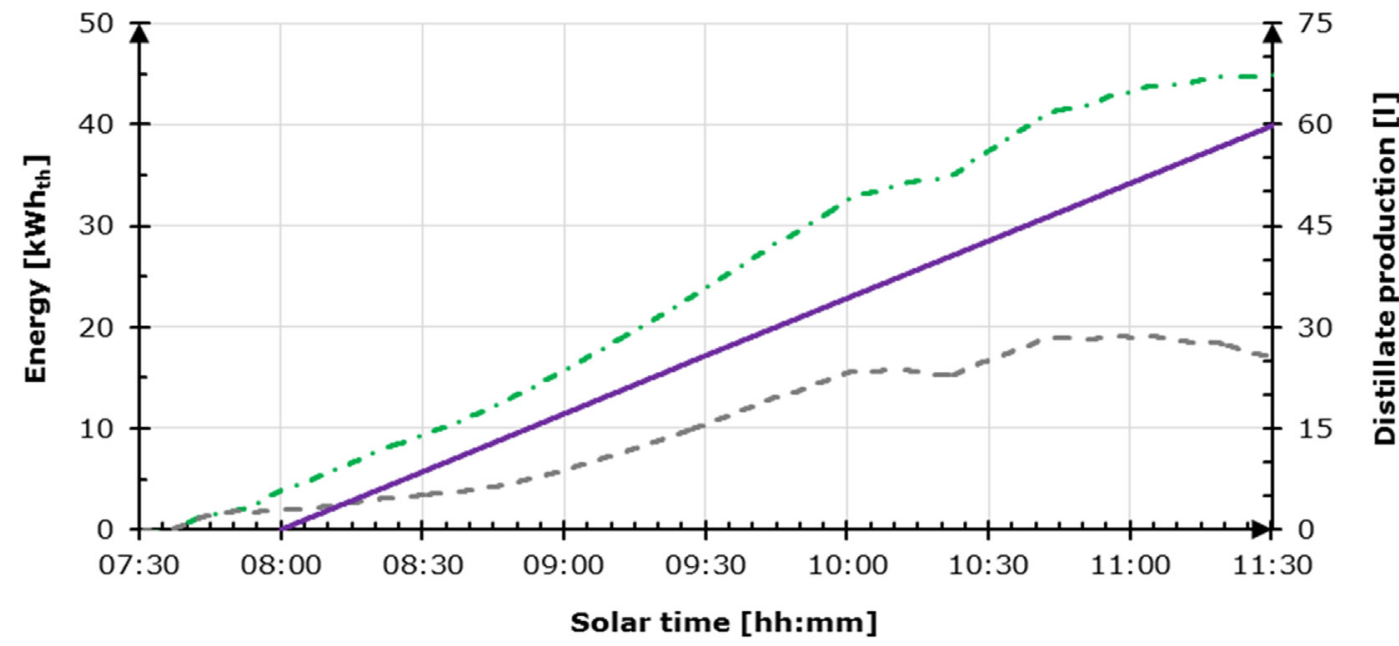

- - Captured solar energy _ - - Stored solar energy Distillate production

Fig. 5. Accumulated energy and distillate production in the experiment performed in a cloudy day.

Fig. 7 shows that the production of distillate was uniform with time because the feed temperature was constant during all the experiment, even in the absence of solar radiation.

Therefore, it was proved that the system was able to deal with variations in the solar radiation to guarantee constant supply of distillate during its operation. The operation can be extended beyond solar radiation availability by reducing the supplied thermal power, but reducing the distillate production too. On the contrary, if a bigger amount of water is necessary in a short time, the operation must be shorter and at a higher feed temperature.

\section{Simulation of the annual performance of the system}

After describing the operation strategies of the solar V-MEMD facility and demonstrating how the variability of the solar radiation can be managed, the following step was to carry out an annual evaluation. For that purpose, a model was made to simulate the annual performance of the system considering the effect of the operating parameters on the distillate production over a full year, to assess the best way of using the heat and check how the system can be operated at maximum efficiency.

\subsection{Modelling}

The model was composed of three main subsystems: the solar field, the storage system, and the MD unit. The variables and parameters of the models mentioned in the following subsections are described in the nomenclature section.

\subsubsection{The solar field model}

The fluid temperature at the outlet of the solar field was evaluated with the bilinear model described in Eq. (1). This model has been widely used with good results in parabolic through collectors [48], compound parabolic collectors [49] and flat-plate collectors [50]. In this case, it was assumed that the dynamic of this solar field was equivalent to the dynamic of one absorber pipe with the following characteristics: the mass flow rate, $\dot{m}_{e q}$, was calculated with Eq. (2) [51] (to take into account that the solar field was composed of 5 collectors in parallel connection and each collector had 10 absorber pipes in parallel) and its length, $L_{e q}$, was three times one real pipe length (to take into account that each loop had three collectors in series connection).

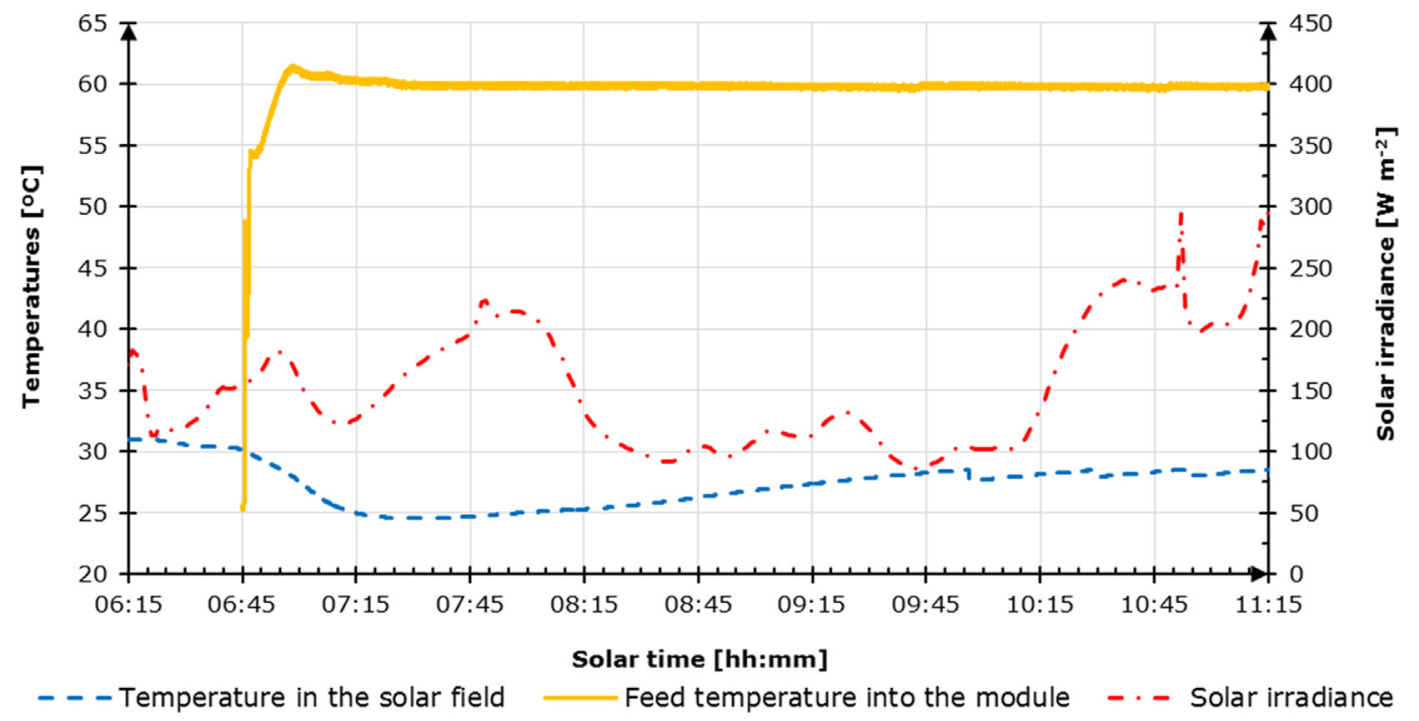

Fig. 6. System temperatures and solar radiation in the experiment performed with only stored heat. 


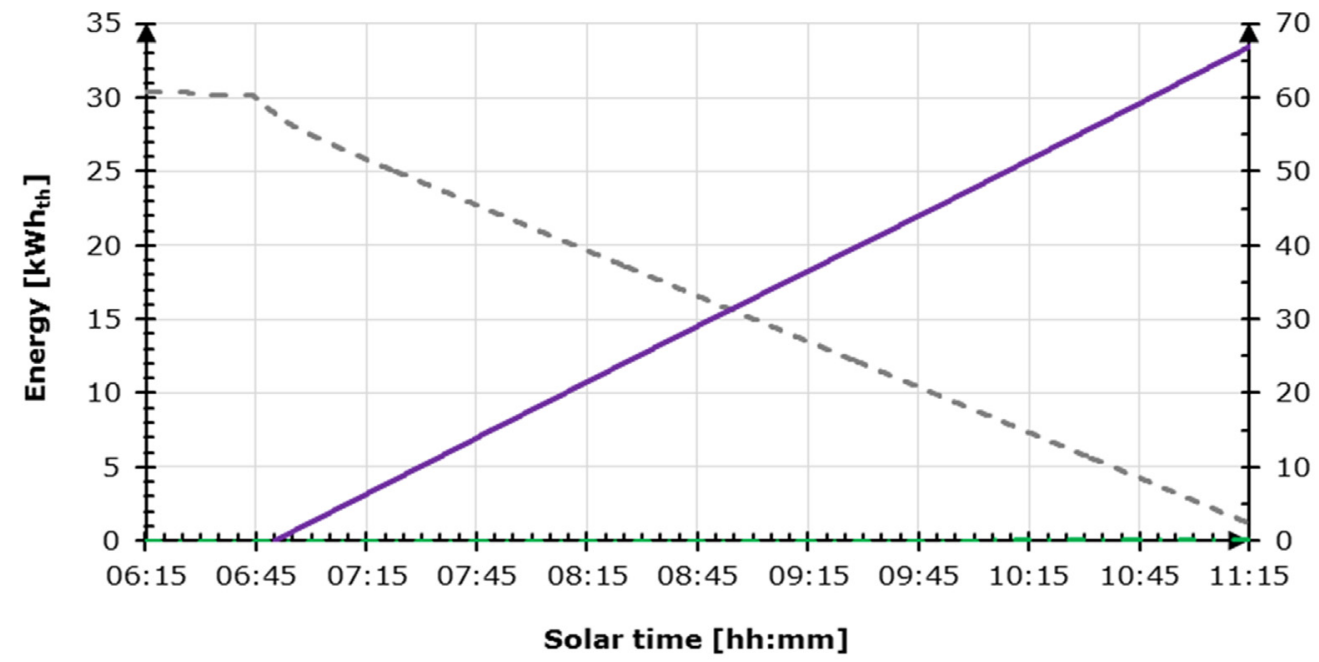

- - Captured solar energy - - Stored solar energy Distillate production

Fig. 7. Accumulated energy and distillate production in the experiment performed with only stored heat.

$$
\begin{aligned}
\rho c_{p} A_{s} \frac{d T_{s, \text { out }}(t)}{d t}= & \beta I(t)-\frac{H}{L_{e q}}\left(\bar{T}_{s}(t)-T_{a}(t)\right) \\
& -c_{p} \dot{m}_{e q} \frac{\left(T_{s, \text { out }}(t)-T_{s, \text { in }}(t)\right)}{L_{e q}},
\end{aligned}
$$

where $\bar{T}_{S}(t)=\frac{T_{s, \text { out }}(t)+T_{s, \text { in }}(t)}{2}$

$\dot{m}_{e q}=\frac{\dot{m}_{s}}{n_{p} \cdot n_{a}}, L_{e q}=L \cdot n_{s}$.

Table 1 includes information about the values of the parameters considered in the solar field model.

\subsubsection{The storage system model}

The heat storage tank was modelled with a stratified multimode approach [48]. The tank was divided into two sections, and an energy balance was applied in each one of these sections:

$$
\begin{aligned}
\rho V & \frac{\partial T_{t 1}(t)}{\partial t} \\
= & \dot{m}_{s}(t) \cdot T_{s, \text { out }}(t)+\dot{m}_{t}(t) \cdot T_{t 2}(t)-\dot{m}_{s}(t) \cdot T_{t 1}(t)-\dot{m}_{t} \\
& (t) \cdot T_{t 1}(t)-\frac{U A_{1} \cdot\left(T_{t 1}(t)-T_{a}(t)\right)}{c_{p}}, \\
\rho V & \frac{\partial T_{t 2}(t)}{\partial t} \\
= & \dot{m}_{S}(t) \cdot T_{t 1}(t)+\dot{m}_{t}(t) \cdot T_{h x, \text { out }}(t)-\dot{m}_{s}(t) \cdot T_{t 2}(t)-\dot{m}_{t} \\
& (t) \cdot T_{t 2}(t)-\frac{U A_{2} \cdot\left(T_{t 2}(t)-T_{a}(t)\right)}{c_{p}},
\end{aligned}
$$

where the volume, $V$, was $1.5 \mathrm{~m}^{3}$, and the thermal losses coefficients, $U A_{1}$ and $U A_{2}$, were $3.6 \mathrm{~J} \cdot \mathrm{s}^{-1} \cdot{ }^{\circ} \mathrm{C}^{-1}$ and $3.8 \mathrm{~J} \cdot \mathrm{s}^{-1} \cdot{ }^{\circ} \mathrm{C}^{-1}$, respectively.

\subsubsection{The MD unit model}

From the results presented in [44] and using the Matlab System Identification toolbox, a static model was obtained to calculate the temperatures at the outlet of the MD unit $\left(T_{m d, \text { out }}\right)$ and heat exchanger $\left(T_{h x, \text { out }}\right)$, and the distillate production $(d)$ when $\dot{\mathrm{m}}_{\mathrm{md}}$ was about $181 \mathrm{~min}^{-1}$. It is described in Eqs. (5)-(8) and in Table 2.

$$
\begin{aligned}
& \mathrm{T}_{\mathrm{md}, \text { in }}=\mathrm{p}_{00}+\mathrm{p}_{01} \cdot \mathrm{T}_{\mathrm{md}, \text { out }}+\mathrm{p}_{02} \cdot \mathrm{T}_{\mathrm{hx}, \text { in }} \\
& \mathrm{T}_{\mathrm{hx} \text {,out }}=\mathrm{p}_{10}+\mathrm{p}_{11} \cdot \mathrm{T}_{\mathrm{md}, \text { out }}+\mathrm{p}_{12} \cdot \mathrm{T}_{\mathrm{hx}, \text { in }} \\
& \mathrm{T}_{\mathrm{md}, \text { out }}=\mathrm{p}_{20}+\mathrm{p}_{21} \cdot \mathrm{T}_{\mathrm{md}, \text { in }}+\mathrm{p}_{22} \cdot \mathrm{T}_{\mathrm{sw}}+\mathrm{p}_{23} \cdot \mathrm{T}_{\mathrm{md, \text {in }}}^{2}+\mathrm{p}_{24} \cdot \mathrm{T}_{\mathrm{md, \text {in }}} \cdot \mathrm{T}_{\mathrm{sw}}
\end{aligned}
$$

$\mathrm{d}=\mathrm{p}_{30}+\mathrm{p}_{31} \cdot \mathrm{T}_{\mathrm{md}, \text { in }}+\mathrm{p}_{32} \cdot \mathrm{T}_{\mathrm{sw}}+\mathrm{p}_{33} \cdot \mathrm{T}_{\mathrm{md}, \text { in }}^{2}+\mathrm{p}_{34} \cdot \mathrm{T}_{\mathrm{md}, \text { in }} \cdot \mathrm{T}_{\mathrm{sw}}+\mathrm{p}_{35} \cdot \mathrm{T}_{\mathrm{sw}}^{2}$

The root mean squared errors obtained with the polynomial approximations described in Eqs. (5)-(8) were $0.7{ }^{\circ} \mathrm{C}, 0.4{ }^{\circ} \mathrm{C}, 0.8{ }^{\circ} \mathrm{C}$ and $2.41 \cdot \mathrm{h}^{-1}$ for $T_{m d, i n}, T_{h x, \text { out }}, T_{m d, \text { out }}$ and $d$, respectively.

\subsection{Operating modes}

Four operating modes were defined in this facility for the purpose of the model:

- Stop mode (mode 0). In this operating mode, all the pumps (solar and process pumps) are stopped and no distillate production is obtained

- MD mode (mode 1). The solar pump is stopped because the solar irradiance is low, but the MD unit is operating with the heat from the storage system (the process pump is running).

- Solar field mode (mode 2). Solar fluid is circulating through the solar field to increase the temperature of the fluid inside the storage system, but the thermal energy is not enough to operate the MD unit. In this operating mode the solar pump is running, the process pump is stopped and the flow path in the solar three-way valve is through position II.

- Full mode (mode 3). The MD unit is in operation and solar fluid is pumped to the solar field to increase the temperature in the storage system. In this operating mode the solar and process pumps are running and the flow path in the solar three-way valve is through position II.

The conditions to change the operating mode were the following ones:

Table 1

Parameters of the solar field model.

\begin{tabular}{ll}
\hline $\mathrm{A}_{\mathrm{s}}$ & $2.8 \cdot 10^{-5} \mathrm{~m}^{2}$ \\
$\mathrm{H}$ & $5.88 \mathrm{~J} \cdot \mathrm{s}^{-1} \cdot{ }^{\circ} \mathrm{C}^{-1}$ \\
$\mathrm{~L}$ & $2.1 \mathrm{~m}$ \\
$\mathrm{~L}_{\mathrm{eq}}$ & $6.3 \mathrm{~m}$ \\
$\mathrm{n}_{\mathrm{a}}$ & 10 \\
$\mathrm{n}_{\mathrm{p}}$ & 5 \\
$\mathrm{n}_{\mathrm{s}}$ & 3 \\
$\beta$ & $0.11 \mathrm{~m}$ \\
\hline
\end{tabular}


Table 2

Variables and parameters of the membrane unit model.

\begin{tabular}{ll}
\hline Model parameters & Value \\
\hline $\mathrm{p}_{00}$ & $15.4151{ }^{\circ} \mathrm{C}$ \\
$\mathrm{p}_{01}$ & 0.1552 \\
$\mathrm{p}_{02}$ & 0.6030 \\
$\mathrm{p}_{10}$ & $11.7460{ }^{\circ} \mathrm{C}$ \\
$\mathrm{p}_{11}$ & 0.1942 \\
$\mathrm{p}_{12}$ & 0.6585 \\
$\mathrm{p}_{20}$ & $158.4438^{\circ} \mathrm{C}$ \\
$\mathrm{p}_{21}$ & -5.0411 \\
$\mathrm{p}_{22}$ & 1.1551 \\
$\mathrm{p}_{23}$ & $0.0474{ }^{\circ} \mathrm{C}^{-1}$ \\
$\mathrm{p}_{24}$ & $-0.0169^{\circ} \mathrm{C}^{-1}$ \\
$\mathrm{p}_{30}$ & $-437.72421 \cdot \mathrm{h}^{-1}$ \\
$\mathrm{p}_{31}$ & $14.26191 \cdot \mathrm{h}^{-1} \cdot{ }^{\circ} \mathrm{C}^{-1}$ \\
$\mathrm{p}_{32}$ & $-6.41801 \cdot \mathrm{h}^{-1} \cdot{ }^{\circ} \mathrm{C}^{-1}$ \\
$\mathrm{p}_{33}$ & $-0.07771 \cdot \mathrm{h}^{-1} \cdot{ }^{\circ} \mathrm{C}^{-2}$ \\
$\mathrm{p}_{34}$ & $-0.08121 \cdot \mathrm{h}^{-1} \cdot{ }^{\circ} \mathrm{C}^{-2}$ \\
$\mathrm{p}_{35}$ & $0.25411 \cdot \mathrm{h}^{-1} \cdot{ }^{\circ} \mathrm{C}^{-2}$ \\
\hline
\end{tabular}

E1: $\left(T_{s, \text { out }}>T_{t 1}+3{ }^{\circ} \mathrm{C}\right) \operatorname{AND}\left(T_{s, \text { out }}<100{ }^{\circ} \mathrm{C}\right)$,

E2: $\left(T_{s, \text { out }}<T_{t 1}+1{ }^{\circ} \mathrm{C}\right) \operatorname{OR}\left(T_{s, \text { out }}>115{ }^{\circ} \mathrm{C}\right)$,

E3: $: T_{t 1}>70{ }^{\circ} \mathrm{C}$

E4: $T_{t 1}<65{ }^{\circ} \mathrm{C}$,

where E1 was the condition to run the solar field pump because it assured that the temperature at the outlet of the solar field, $T_{s, \text { out }}$, was on one hand, higher enough (by $3^{\circ} \mathrm{C}$ ) than the temperature in the upper part of the tank, $T_{t 1}$, to avoid cooling it, and on the other hand, lower than $100{ }^{\circ} \mathrm{C}$ to avoid water evaporation. E2 was used to stop the solar field to prevent cooling down the tank (when $T_{\text {s,out }}$ is lower than $\left.T_{t 1}+1{ }^{\circ} \mathrm{C}\right)$ or water evaporation $\left(T_{s, \text { out }}\right.$ higher than $\left.115^{\circ} \mathrm{C}\right)$. It is important to mention that the constant values used in conditions $\mathrm{E} 2$ and E3 were not the same in order to reduce the frequency of switching between operating modes when the variables are close to the conditions. E3 was used to know if there was enough temperature in the tank to operate the MD unit and E4 informed that the temperature in the tank was low and the MD had to be stopped.

The state graph was the one shown in Fig. 8.

Fig. 9 shows an example to better understand how the transitions between operating modes were made. At the beginning of the day, there was no enough temperature neither at the outlet of the solar field nor in the upper part of the tank, so the facility was in stop mode (mode 0). When the solar irradiance increased, the temperature at the outlet of the solar field exceed $T_{t 1}$ and condition E1 was activated, so the operating mode changed to solar field mode (mode 2) and the temperature in the tank started to increase. At about 9:30 UTC, $T_{t 1}$ reached $70{ }^{\circ} \mathrm{C}$ and therefore, condition E3 was activated and the operating mode changed to full mode (mode 3, MD and solar field in operation). This operating mode was maintained until 13:00 UTC. At that time, solar irradiance was decreasing, condition E2 was activated due to $T_{s, \text { out }}<T_{t 1}+1{ }^{\circ} \mathrm{C}$, the operating mode was changed to MD mode (mode 1 ) and the solar pump was stopped. During more than $1 \mathrm{~h}$ and a half the MD unit could produce distillate with the thermal energy stored in the tank. When $T_{t 1}<65^{\circ} \mathrm{C}$, condition $\mathrm{E} 4$ was activated and the operating mode changed to stop mode (mode 0).

\subsection{Temperature control}

A control strategy was included in the model to maintain the temperature at the inlet of the membrane module, $T_{m d \text {,in }}$ at three different setpoints: $60^{\circ} \mathrm{C}, 70^{\circ} \mathrm{C}$ and $80^{\circ} \mathrm{C}$, in order to consider different strategies for using the heat. Firstly, from the setpoint and the actual $T_{m d, \text { out }}$ values, the required temperature at the inlet of the membrane unit, $T_{h x, \text { in }}$ was inferred through the inverse of Eq. (5). Based on a heat and mass balance in steady state conditions, the control 3-way valve aperture, $\gamma$, (Fig. 1) required to reach the desired temperature $T_{h x, i n}$ was calculated. In this model, it was assumed that this valve is an ideal linear actuator:

$T_{h x, \text { in }} \cdot c_{p}\left(T_{h x, \text { in }}\right)=T_{t 1} \cdot c_{p}\left(T_{t 1}\right) \cdot \gamma+T_{h x . \text { out }} \cdot c_{p}\left(T_{h x, \text { out }}\right) \cdot(1-\gamma)$

$\gamma=\frac{T_{h x, \text { in }} \cdot c_{p}\left(T_{h x, \text { in }}\right)-T_{h x . \text { out }} \cdot c_{p}\left(T_{h x, \text { out }}\right)}{T_{t 1} \cdot c_{p}\left(T_{t 1}\right)-T_{h x . \text { out }} \cdot c_{p}\left(T_{h x, \text { out }}\right)}$

\subsection{Inputs of the model simulations}

With the aim of performing an annual simulation, the following assumptions were made:

- The solar irradiance at titled angle $\left(45^{\circ}\right)$ and the ambient temperature were obtained from the Photovoltaic Geographical Information System (PVGIS) tool [52]. PVGIS is a free online tool aimed to estimate the solar electricity production of a photovoltaic (PV) system. It provides solar radiation and ambient temperature based on data from satellites. The data base used was PVGIS-CMSAF and the chosen location was University of Almería (36.830, -2.404). The data obtained are depicted in Fig. 10. As can be observed, the highest values of solar irradiance were reached near the equinoxes (monthly averages of the irradiation are represented in Fig. 10 for better visual assessment).

- The monthly mean seawater temperature was obtained from the data collected in [53] (see Fig. 10). The chosen location was Almería (Spain).

- When the solar field was operating, the solar fluid flow rate was established as $15 \mathrm{l} / \mathrm{min}$.

- A constant pressure of 2 bar was assumed in the circuit.

- Three different values of MD unit inlet temperature $\left(\mathrm{T}_{\mathrm{md}, \mathrm{in}}\right)$ setpoint (70, 80 and $90^{\circ} \mathrm{C}$ ) were considered.

- $\dot{\mathrm{m}}_{\mathrm{hx}}$ and $\dot{\mathrm{m}}_{\mathrm{md}}$ were equal $\left(181 \mathrm{~min}^{-1}\right)$.

- The initial conditions considered to perform the simulation were the following ones: $\quad T_{t 2}(\mathrm{t}=0)=55^{\circ} \mathrm{C} ; \quad T_{t 1}(\mathrm{t}=0)=70^{\circ} \mathrm{C}$; $T_{m d, \text { out }}(\mathrm{t}=0)=20^{\circ} \mathrm{C} ; T_{s, \text { in }}(\mathrm{t}=0)=T_{t 1} ; T_{s, \text { out }}(\mathrm{t}=0)=T_{t 2}$.

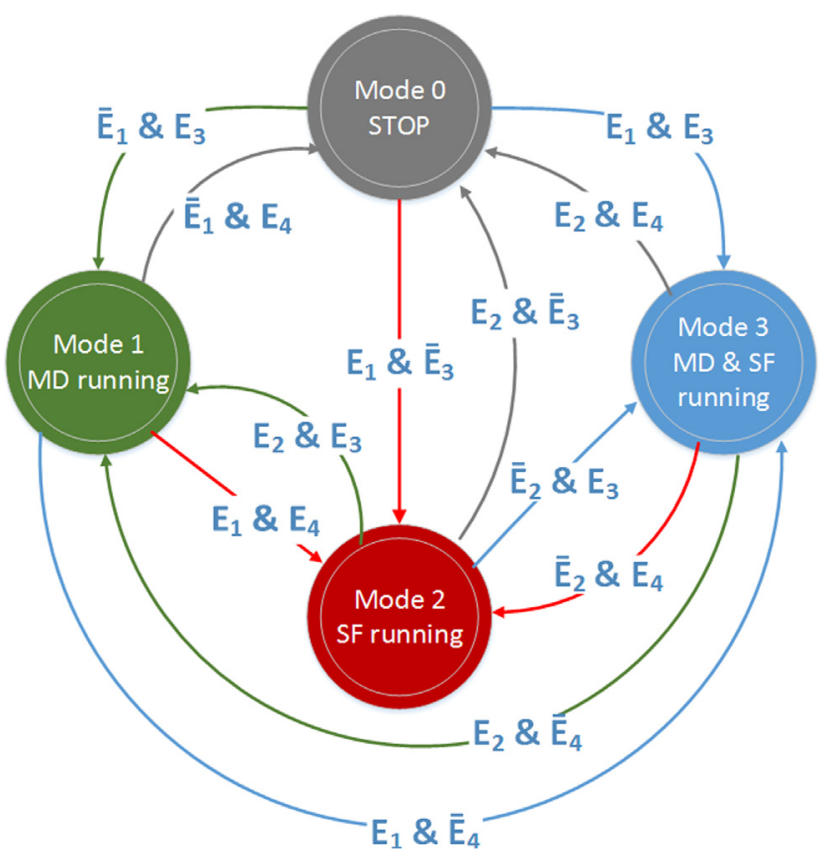

Fig. 8. State diagram considered to operate the SMD facility in the simulation of the annual performance. The basic operations of Boolean algebra included in the state diagram are $\bar{x}=\operatorname{NOT}(x) ; x \& y=x$ AND $y$. 

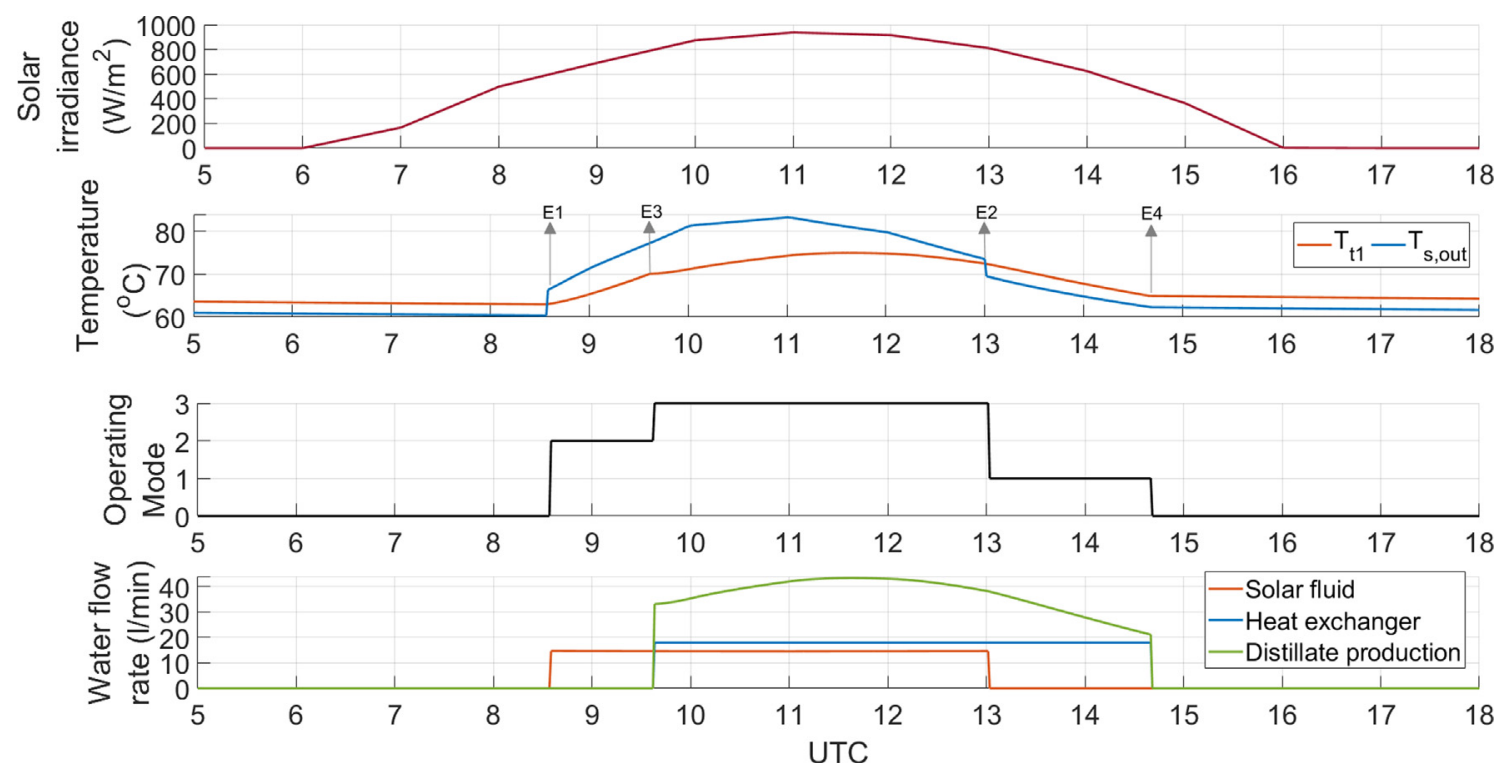

Fig. 9. Operating modes simulated during a sunny day.

\subsection{Simulation results}

The model was run for simulating the system behavior during a typical year, considering three different operating values of the temperature inlet to the MD module. In order to reduce the computation time, the dynamic models were discretized using the finite difference method. The sampling time used was $60 \mathrm{~s}$, to obtain a trade-off between execution time and the error obtained with the discretization.

The distillate production calculated with the model is shown in Fig. 11. The total productions during the whole year were 41.7, 68.4 and $70.5 \mathrm{~m}^{3}$ considering the heat used at different temperature setpoints of $60{ }^{\circ} \mathrm{C}, 70^{\circ} \mathrm{C}$ and $80^{\circ} \mathrm{C}$, respectively. According to the physics of the MD process, the higher the operating temperature is, the larger the distillate production is, as long as the system is kept in the optimal operational range (see our previous study [44]). Moreover, as can be observed, the difference between the first and second case is much larger than between the second and third. Following the exponential dependence of the vapour pressure with the temperature, these differences should be inversely related. However, it must be considered that although the setpoint was established at a fixed value, the controller could only maintain it when the conditions were favorable. As shown in Table 3 , in the case of the lowest setpoint $\left(60^{\circ} \mathrm{C}\right)$, almost $100 \%$ of the operation took place at that value, in the case of $70{ }^{\circ} \mathrm{C} 31.8 \%$, and in the case of $80^{\circ} \mathrm{C}$, only $2.6 \%$ of the time $T_{m d \text {,in }}$ was maintained at the setpoint. To understand this, Figs. 2 and 4 can be invoked. While in the latter the setpoint of $60^{\circ} \mathrm{C}$ was reached almost immediately after starting the MD operation, in the former it took longer to reach the setpoint of $80^{\circ} \mathrm{C}$, and this was only possible in a clear day with good conditions. This maximum setpoint, therefore, can be seen as equivalent to operating using the heat without limitations, while the minimum setpoint of $60^{\circ} \mathrm{C}$ restricts the temperature to facilitate the extension of the operation using the stored heat, as illustrated in Figs. 5 and 7.

The highest monthly values of distillate production were obtained during the late summer, when high solar irradiance at 45 coincided
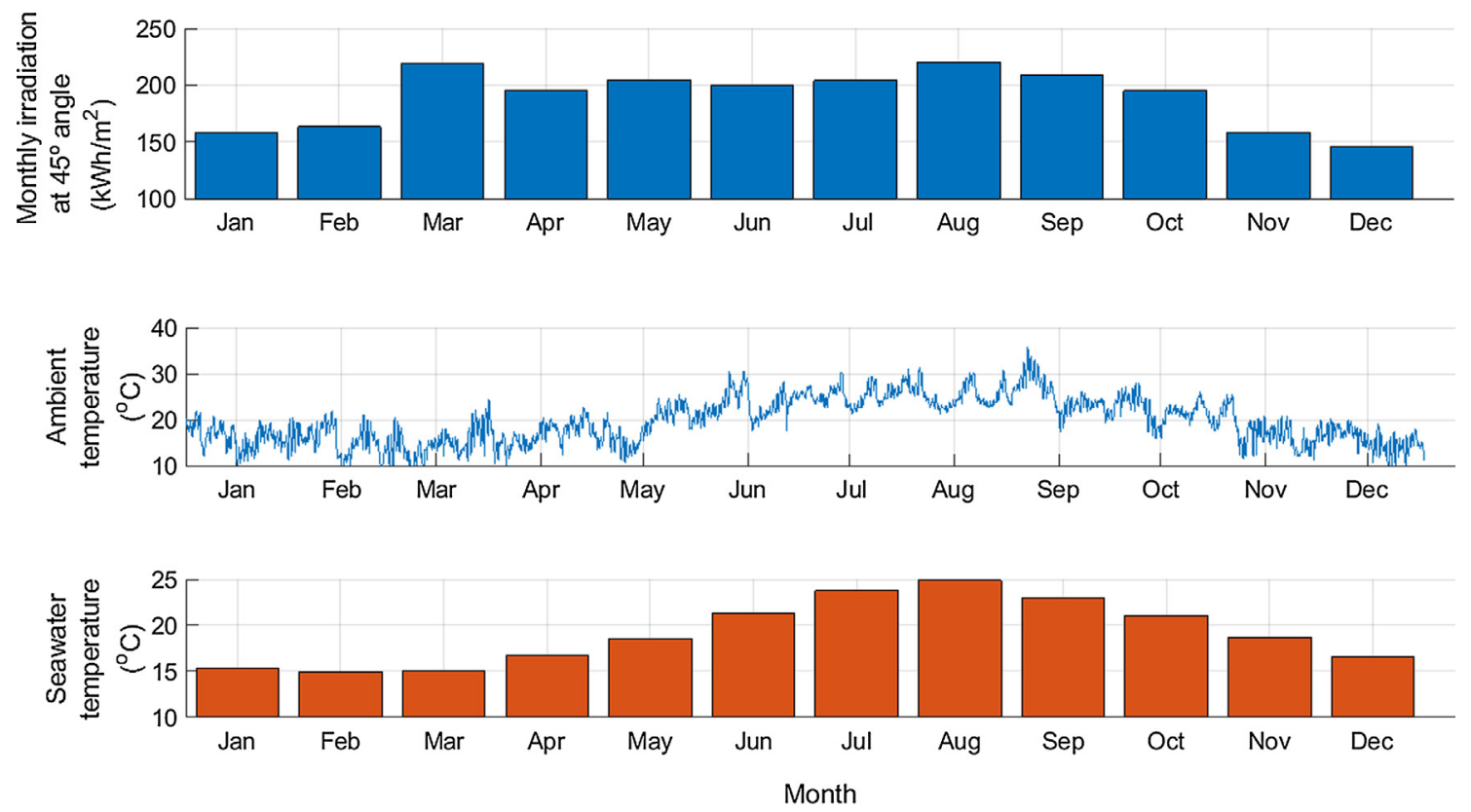

Fig. 10. Inputs used for the annual simulation. 


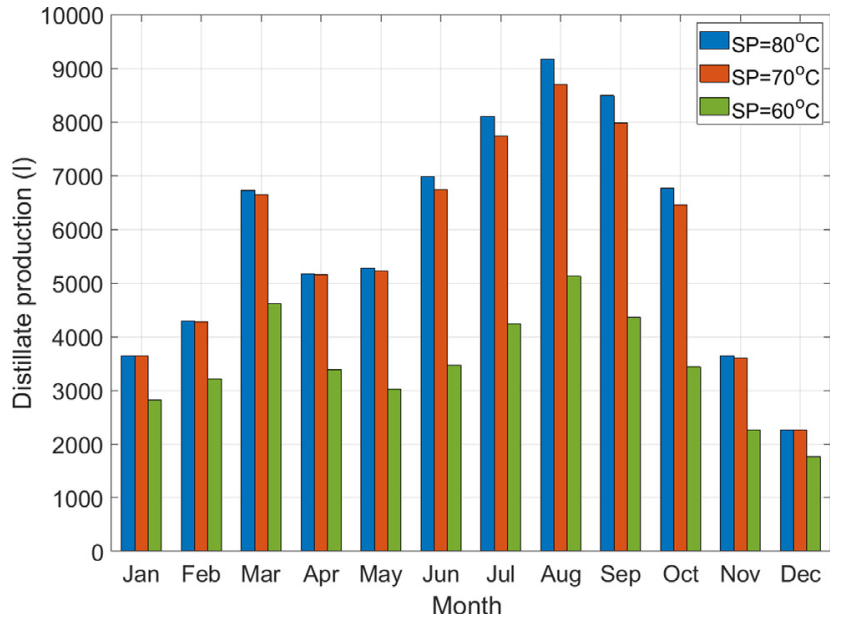

Fig. 11. Monthly distilled water production. Comparison performed with different temperature setpoints (SP) at the inlet of the MD module $\left(T_{m d, i n}\right)$.

Table 3

Distribution of the operating temperature of $\mathrm{MD}$ corresponding to each setpoint: time in hours that $T_{m d, \text { in }}$ was kept inside every interval.

\begin{tabular}{llll}
\hline Setpoint SP & Time (h) & \\
\cline { 2 - 4 } & $\mathrm{T}_{\mathrm{md}, \text { in }}=\mathrm{SP} \pm 1{ }^{\circ} \mathrm{C}$ & $\begin{array}{l}\mathrm{SP}-9{ }^{\circ} \mathrm{C}<\mathrm{T}_{\mathrm{md}, \text { in }}<\mathrm{SP} \\
-1{ }^{\circ} \mathrm{C}\end{array}$ & $\begin{array}{l}\mathrm{T}_{\mathrm{md}, \text { in }} \leq \mathrm{SP}- \\
9{ }^{\circ} \mathrm{C}\end{array}$ \\
\hline $80^{\circ} \mathrm{C}$ & 55.4 & 408.1 & 1684.1 \\
$70^{\circ} \mathrm{C}$ & 683.3 & 1219.7 & 249 \\
$60^{\circ} \mathrm{C}$ & 2535.5 & 0.9 & 0 \\
\hline
\end{tabular}

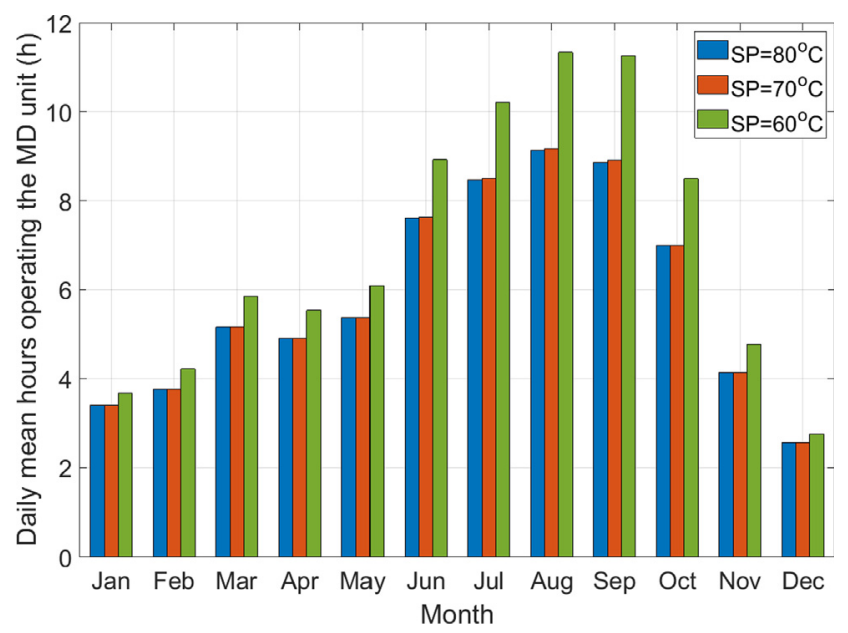

Fig. 12. Daily mean operating time of the MD unit. Comparison performed with different temperature setpoints (SP) at the inlet of the MD module.

with high ambient temperature, so the heat losses in the solar field decreased. The strong influence of the ambient temperature was observed comparing April and October with similar irradiance. Production in the latter month was larger because ambient temperature was higher. The largest values of distillate production were strongly linked with the temperature setpoint at the inlet of the MD module $\left(T_{m d, i n}\right)$. It could be at its highest values $\left(80^{\circ} \mathrm{C}\right)$ when the solar field was at its highest efficiency, and this took place during the late summer months because of the more abundance of clear days and the fact that the energy stored allowed operating at temperatures close to $80^{\circ} \mathrm{C}$, whereas in winter months the system could barely reach $70^{\circ} \mathrm{C}$. The effect of the seawater temperature was also important and was evident in the fact that the maximum production occurred in September, with less irradiance and ambient temperature than in August, but also less seawater temperature. As a consequence of the better solar field efficiency during the summer, the operating time of the MD unit in this period was twice than in winter (see Fig. 12). It is important to mention that the operation at lower setpoint temperatures increased the operating time of the MD because the use of the stored energy was more distributed along the time.

The use of the solar field also presented some differences along the year (see Fig. 13). In this case, working at higher temperatures at the inlet of the MD module increased the operating time of the solar field (mainly during the summer). The reason was that when a lower setpoint temperature was used during summer, the heat extraction from the solar collectors took place at a lower rate and the temperature at the outlet of the solar field could reach the maximum temperature established $\left(115^{\circ} \mathrm{C}\right)$ for the solar field to stop. This situation occurred because when working at low setpoint temperatures in the MD the energy stored was higher and the temperature at the inlet of the solar field was closer to the maximum temperature. However, the increase in operation time during the summer was less for the solar field than for the MD module, with extended functioning due to the energy stored when the daily solar radiation was larger. As a matter of fact, only in January and December the operating time of the solar field exceeded that of the MD, because of the low radiation demanding a longer time to reach the setpoint value of the operating temperature and the lack of possibilities to store heat. During the rest of the year, the solar field was operating a shorter time than the MD, because the latter's functioning was extended due to the available stored heat. Indeed, this difference of operating time was more noticeable for the $60^{\circ} \mathrm{C}$ setpoint, which allowed a more prolonged use of the stored heat.

Summarizing all the results, during a typical year the difference between operating at $80{ }^{\circ} \mathrm{C}$ and $70{ }^{\circ} \mathrm{C}$ was $3.1 \%$ more production, with only $0.2 \%$ less MD operating time and $3 \%$ more solar field operating time, while the difference between operating at a setpoint of $70{ }^{\circ} \mathrm{C}$ and $60{ }^{\circ} \mathrm{C}$ was $64 \%$ more production with $15.2 \%$ less MD operating time and $18.5 \%$ longer solar field operating time. It is evident that working with the heat at its lowest temperature hinders greatly the distillate production, and the decrease of solar field operation time is balanced by the increase of MD operation time. It is not within the scope of this article to perform an economic analysis, mainly because the costs of this novel V-MEMD technology are not yet established (the technology is not commercially implemented). However, some economic consideration can be used to assess the results. It has been sufficiently established that operational costs (excluding thermal energy) are not the highest in MD [21,54]. It can be assumed that the operating costs of the MD and the solar field are mostly due to the associated electric consumption in each case. The power consumed by the V-MEMD unit is about $300 \mathrm{~W}$ (due to the vacuum pump and circulation pumps), and that for the solar field (mainly two circulation pumps) can be estimated at about $500 \mathrm{~W}$. The $18.5 \%$ increase of operating time of the solar field would result roughly in about $124 \mathrm{kWh}$ additional electrical consumption, and the $15.2 \%$ reduction of $\mathrm{MD}$ operating time in about $115 \mathrm{kWh}$ less consumption. An increase of the production by $64 \%$ can clearly offset the additional cost of electricity. The case of changing the setpoint from $70{ }^{\circ} \mathrm{C}$ to $80^{\circ} \mathrm{C}$ is not so clear, but even if a high cost is considered for the electricity ( $0.32 \$ / \mathrm{kWh}$ ), the cost of the additional $35 \mathrm{kWh}$ due to the longer operation of the solar field cannot offset the value of the additional $3.1 \%$ more production as long as the water production cost is not below $5.2 \$ / \mathrm{m}^{3}$. Considering that an estimate of the cost of the water produced by MD due only to the solar heat is about $5.2 \$ / \mathrm{m}^{3}$ [17], and that figure is estimated for a system producing $10 \mathrm{~m}^{3} /$ day with a specific thermal energy consumption that is half that of the V-MEMD unit of this work, it can be concluded that the additional production is more beneficial than the additional operating time.

Thus, the larger relative increase of production when increasing the temperature setpoint will have a greater beneficial effect on the costs. In addition, as shown in Fig. 14 the distillate flux was larger and very 


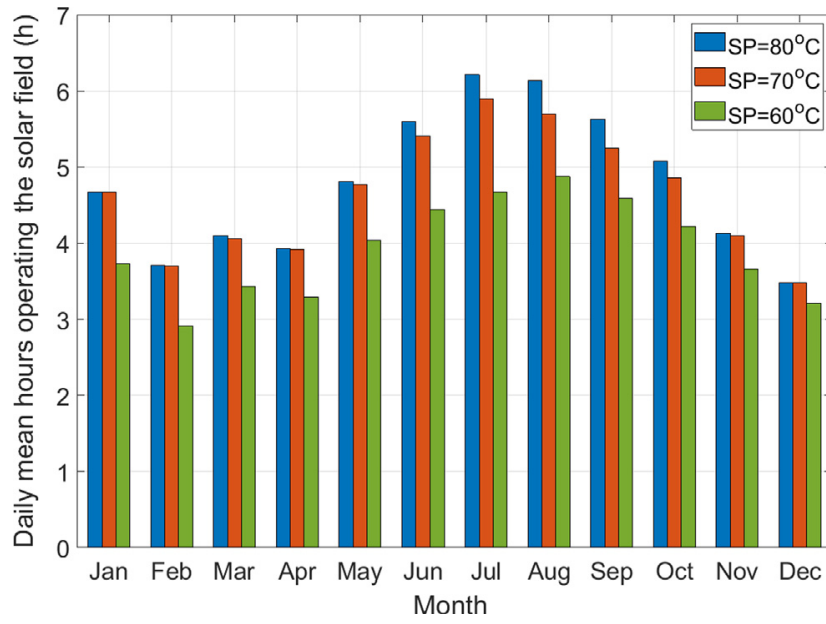

Fig. 13. Daily mean operating time of the solar field. Comparison performed with different temperature setpoints (SP) at the inlet of the MD module.

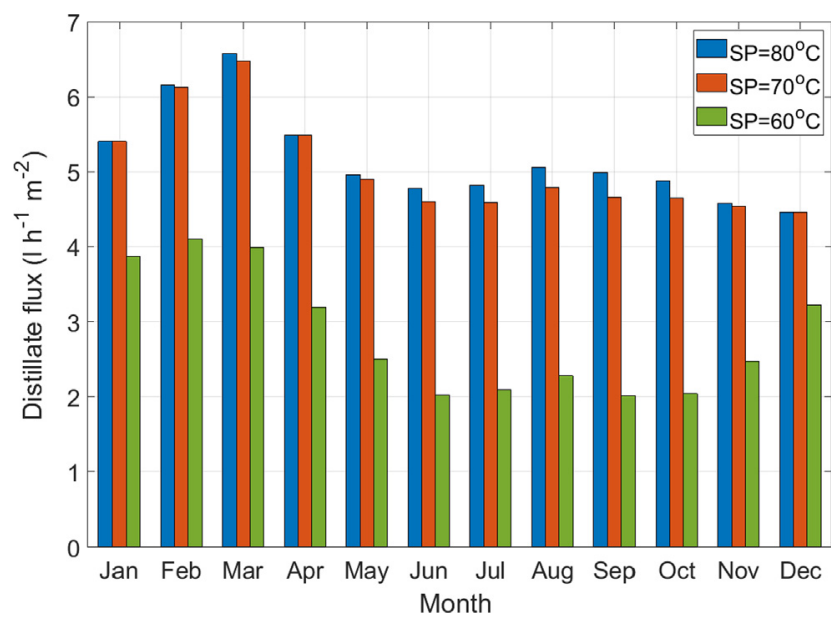

Fig. 14. Mean monthly distillate fluxes obtained along the year with different setpoints (SP) at the inlet of the MD unit $\left(\mathrm{T}_{\mathrm{hx}, \mathrm{in}}\right)$.

similar for the setpoints of $80^{\circ} \mathrm{C}$ and $70^{\circ} \mathrm{C}$ than for $60^{\circ} \mathrm{C}$, and also more stable, with an average value of $(5.5 \pm 1) 1 \mathrm{~h}^{-1} \mathrm{~m}^{-2}$ vs. $(3 \pm 1) 1 \mathrm{~h}^{-1}$ $\mathrm{m}^{-2}$, respectively. This behaviour indicates that the MD module was more efficiently used for the higher setpoints. Fig. 14 also shows the beneficial effect of a lower seawater temperature on the specific performance of the V-MEMD unit, since for a given operating temperature the maximum distillate flux values always coincide with the minimum seawater temperature values (see Fig. 10). This effect is stronger the lower the operating temperature, since this enhances the effect of the cooling temperature on the MD unit [44]. Regarding the choice between the setpoints of $80^{\circ} \mathrm{C}$ and $70^{\circ} \mathrm{C}$, the longer operating time of the solar field in the former case was reflected in a similar relative production increase without any influence on the MD operation time. Thus, it seems beneficial to choose the highest setpoint temperature for the solar heat.

\section{Conclusions}

In this work, the use of solar energy as thermal source for the production of distilled water from Mediterranean seawater with the vacuum multi-effect membrane distillation unit MDS-40B was evaluated. A solar field of flat plate collectors with total power up of $17 \mathrm{~kW}_{\text {th }}$ at $90^{\circ} \mathrm{C}$ was used for energy harvesting, connected to a heat buffer tank. The design of the solar field allowed working almost the whole year in a wide range of feed temperatures in the MD module, between 60 and $80^{\circ} \mathrm{C}$. It was shown that the use of a heat buffer in the desalination system made the operation more stable when perturbations in solar radiation occurred. The feed temperature could be maintained inside the operating range of $60^{\circ} \mathrm{C}$ and $70^{\circ} \mathrm{C}$ in the membrane module despite changes in the solar radiation, and it was shown that the heat stored in the tank during a day of operation was enough to operate the following day during a similar length of time without solar radiation, although at a lower temperature. Reaching an operating temperature of $80^{\circ} \mathrm{C}$ proved more difficult, though, and only possible during $2.6 \%$ of the operating time during a typical year. A simulation of the system showed that a total production of $41.7,68.4$ and $70.5 \mathrm{~m}^{3}$ can be obtained for a setpoint of $60{ }^{\circ} \mathrm{C}, 70^{\circ} \mathrm{C}$ and $80^{\circ} \mathrm{C}$, respectively. The large decrease of production when using the heat at $60^{\circ} \mathrm{C}$ maximum temperature makes it unworthy and hardly balanced by the operational expenses. Using the heat at $70^{\circ} \mathrm{C}$ was a better option, and even the small production increase when allowing for a maximum temperature of $80^{\circ} \mathrm{C}$ was worthwhile, since the increment in the operational expenses was rather low compared to $70^{\circ} \mathrm{C}$. It was demonstrated that the controlled operation of the solar field managed to balance the competing effects between solar irradiance, seawater temperature and availability of solar thermal energy to optimize the performance of the membrane distillation unit.

\section{Declaration of Competing Interest}

The authors declare that they have no known competing financial interests or personal relationships that could have appeared to influence the work reported in this paper.

\section{Acknowledgements}

The authors wish to thank the financial support given by the National $\mathrm{R}+\mathrm{D}+\mathrm{i}$ Plan Project DPI2017-85007-R of the Spanish Ministry of Science, Innovation and Universities, as well as the SolarNOVA project (ICT-CEPU2009-0001), co-financed by the Spanish Ministry of Science, Innovation and Universities and ERDF funds.

\section{References}

[1] Lienhard JH, Antar MA, Bilton A, Blanco J, Zaragoza G. Solar desalination. Annu Rev Heat Transf 2012;15:277-347.

[2] Burn S, Hoang M, Zarzo D, Olewniak F, Campos E, Bolto B, et al. Desalination techniques - a review of the opportunities for desalination in agriculture. Desalination 2015;364:2-16.

[3] Reif JH, Alhalabi W. Solar-thermal powered desalination: Its significant challenges and potential. Renew Sustain Energy Rev 2015;48:152-65.

[4] Ghaffour N, Mujtaba IQ. Desalination using renewable energy. Desalination 2018;435:1-2.

[5] Gopi G, Arthanareeswaran G, Ismail AF. Perspective of renewable desalination by using membrane distillation. Chem Eng Res Des 2019;144:520-37.

[6] Tzen E, Zaragoza G, Alarcón-Padilla DC. Solar Desalination. Compr Renew Energy. Elsevier; 2012. p. 529-65.

[7] Ghaffour N, Lattemann S, Missimer T, Ng KC, Sinha S, Amy G. Renewable energydriven innovative energy-efficient desalination technologies. Appl Energy 2014;136:1155-65.

[8] Cipollina A, Tzen E, Subiela V, Papapetrou M, Koschikowski J, Schwantes R. Renewable energy desalination: performance analysis and operating data of existing RES desalination plants. Desalin Water Treat 2015;55:3126-46.

[9] Buenaventura-Pouyfauçon A, García-Rodríguez L. Solar thermal-powered desalination: a viable solution for a potential market. Desalination 2018;435:60-9.

[10] Koschikowski J, Wieghaus M, Rommel M, Subiela V, Suarez BP, BetancortRodríguez JR. Experimental investigations on solar driven stand-alone membrane distillation systems for remote areas. Desalination 2009;248:125-31.

[11] Mathioulakis E, Belessiotis V, Delyannis E. Desalination by using alternative energy: Review and state-of-the-art. Desalination 2007;203:346-65.

[12] Alkhudhiri A, Darwish N, Hilal N. Membrane distillation: a comprehensive review. Desalination 2012;287:2-18.

[13] Khayet M, Matsuura T. Membrane distillation - principles and applications. Elsevier; 2011.

[14] Drioli E, Ali A, Macedonio F. Membrane distillation: recent developments and perspectives. Desalination 2015;356:56-84.

[15] Khayet M. Membranes and theoretical modeling of membrane distillation: a review. Adv Colloid Interface Sci 2011;164:56-88.

[16] Khayet M. Solar desalination by membrane distillation: DISPERSION in energy 
consumption analysis and water production costs (a review). Desalination 2013;308:89-101.

[17] Zaragoza G, Andrés-Mañas JA, Ruiz-Aguirre A. Commercial scale membrane distillation for solar desalination. NPJ Clean Water 2018;1:20.

[18] González D, Amigo J, Suárez F. Membrane distillation: perspectives for sustainable and improved desalination. Renew Sust Energ Rev 2017;80:238-59.

[19] Guillén-Burrieza E, Blanco J, Zaragoza G, Alarcón-Padilla DC, Palenzuela P, Ibarra $\mathrm{M}$, et al. Experimental analysis of an air gap membrane distillation solar desalination pilot system. J Memb Sci 2011;379:386-96.

[20] Guillén-Burrieza E, Zaragoza G, Miralles-Cuevas S, Blanco J. Experimental evaluation of two pilot-scale membrane distillation modules used for solar desalination. J Memb Sci 2012;409:264-75.

[21] Guillén-Burrieza E, Alarcón-Padilla DC, Palenzuela P, Zaragoza G. Techno-economic assessment of a pilot-scale plant for solar desalination based on existing plate and frame MD technology. Desalination 2015;374:70-80.

[22] Winter D, Koschikowski J, Wieghaus M. Desalination using membrane distillation: experimental studies on full scale spiral wound modules. J Memb Sci 2011;375:104-12.

[23] Schwantes R, Cipollina A, Gross F, Koschikowski J, Pfeifle D, et al. Membrane distillation: solar and waste heat driven demonstration plants for desalination. Desalination 2013;323:93-106.

[24] Banat F, Jwaied N, Rommel M, Koschikowski J, Wieghaus M. Performance evaluation of the "large SMADES" autonomous desalination solar-driven membrane distillation plant in Aqaba Jordan. Desalination 2007;217:17-28.

[25] Banat F, Jwaied N, Rommel M, Koschikowski J, Wieghaus M. Desalination by a "compact SMADES" autonomous solar-powered membrane distillation unit. Desalination 2007;217:29-37.

[26] Winter D, Koschikowski J, Ripperger S. Desalination using membrane distillation: flux enhancement by feed water deaeration on spiral-wound modules. J Memb Sci 2012;423-24:215-24.

[27] Ruiz-Aguirre A, Andrés-Mañas JA, Fernández-Sevilla JM, Zaragoza G. Modeling and optimization of a commercial permeate gap spiral wound membrane distillation module for seawater desalination. Desalination 2017;419:160-8.

[28] Ruiz-Aguirre A, Andrés-Mañas JA, Fernández-Sevilla JM, Zaragoza G. Comparative characterization of three commercial spiral-wound membrane distillation modules. Desalin Water Treat 2017;61:152-9.

[29] Ruiz-Aguirre A, Alarcón-Padilla DC, Zaragoza G. Productivity analysis of two spiralwound membrane distillation prototypes coupled with solar energy. Desalin Water Treat 2015;55:2777-85.

[30] Abu-Zeid MAER, Zhang Y, Dong H, Zhang L, Chen HL, Hou L. A comprehensive review of vacuum membrane distillation technique. Desalination 2015;356:1-14.

[31] Mericq JP, Laborie S, Cabassud C. Evaluation of systems coupling vacuum membrane distillation and solar energy for seawater desalination. Chem Eng J 2011;166:596-606.

[32] Ma Q, Ahmadi A, Cabassud C. Direct integration of a vacuum membrane distillation module within a solar collector for small-scale units adapted to seawater desalination in remote places: design, modeling \& evaluation of a flat-plate equipment. J Memb Sci 2018;564:617-33.

[33] Miladi R, Frikha N, Kheiri A, Gabsi S. Energetic performance analysis of seawater desalination with a solar membrane distillation. Energy Convers Manage 2019;185:143-54.
[34] Heinzl W, Büttner S, Lange G. Industrialized modules for MED Desalination with polymer surfaces. Desalin Water Treat 2012;42:177-80.

[35] Zhao K, Heinzl W, Wenzel M, Büttner S, Bollen F, Lange G, et al. Experimental study of the memsys vacuum-multi-effect- membrane-distillation (V-MEMD) module. Desalination 2013;323:150-60.

[36] Zaragoza G, Ruiz-Aguirre A, Guillén-Burrieza E. Efficiency in the use of solar thermal energy of small membrane desalination systems for decentralized water production. Appl Energy 2014;130:491-9.

[37] Wenzel M, Büttner S, Heinzl W, Heinzl S. Distillation of high concentrated salt solution by vacuum multi effect membrane distillation (VMEMD) of memsys. Water Pract Technol 2015;10:478-85.

[38] Mohamed ES, Boutikos P, Mathioulakis E, Belessiotis V. Experimental evaluation of the performance and energy efficiency of a Vacuum Multi-Effect Membrane Distillation system. Desalination 2017;408:70-80.

[39] Ahmed FE, Hashaikeh R, Hilal N. Solar powered desalination - technology, energy and future outlook. Desalination 2019;453:54-76.

[40] Li Q, Beier LJ, Tan J, Brown C, Lian B, Zhong W, et al. An integrated, solar-driven membrane distillation system for water purification and energy generation. Appl Energy 2019;237:534-48.

[41] Chen YH, Li YW, Chang H. Optimal design and control of solar driven air gap membrane distillation desalination systems. Appl Energy 2012;100:193-204.

[42] Andrés-Mañas JA, Palenzuela P, Cornejo L, Alarcón-Padilla DC, Acién FG, Zaragoza G. Preliminary evaluation of the use of vacuum membrane distillation for the production of drinking water in Arica (Chile). Desalin Water Treat 2017;61:160-9.

[43] Chafidz A, Al-Zahrani S, Al-Otaibi MN, Hoong CF, Lai TF, Prabu M. Portable and integrated solar-driven desalination system using membrane distillation for arid remote areas in Saudi Arabia. Desalination 2014;345:36-49.

[44] Andrés-Mañas JA, Ruiz-Aguirre A, Acién FG, Zaragoza G. Assessment of a pilot system for seawater desalination based on vacuum multi-effect membrane distillation with enhanced heat recovery. Desalination 2018;443:110-21.

[45] Gil JD, Roca L, Ruiz-Aguirre A, Zaragoza G, Berenguel M. Optimal operation of a solar membrane distillation pilot plant via nonlinear model predictive control. Comput Chem Eng 2018;109:151-65

[46] Moore SE, Mirchandani SD, Karanikola V, Neno TM, Arnold RG, Sáez AE. Process modeling for economic optimization of a solar driven sweeping gas membrane distillation desalination system. Desalination 2018;437:108-20.

[47] Boutikos P, Mohamed ES, Mathioulakis E, Belessiotis V. A theoretical approach of a vacuum multi-effect membrane distillation system. Desalination 2017;422:25-41.

[48] Cirre CM, Valenzuela L, Berenguel M, Camacho EF. Feedback linearization control for a distributed solar collector field. Control Eng Pract 2007;15:1533-44.

[49] Roca L, Berenguel M, Yebra L, Alarcón-Padilla DC. Solar field control for desalination plants. Sol Energy 2008;82(9):772-86.

[50] Gil JD, Roca L, Zaragoza G, Berenguel M. A feedback control system with reference governor for a solar membrane distillation pilot facility. Renew Energy 2018;120:536-49.

[51] Duffie JA, Beckman WA. Solar engineering of thermal processes. John Wiley and Sons; 1980.

[52] http://re.jrc.ec.europa.eu/pvgis/.

[53] https://www.seatemperature.org/.

[54] Hitsov I, De Sitter K, Dotremont C, Nopens I. Economic modelling and model-based process optimization of membrane distillation. Desalination 2018;436:125-43. 